JOSÉ MÁRCIO DE SOUSA JÚNIOR

\title{
DETERMINAÇÃO DO ÍNDICE DE VOLUME DE PULVERIZAÇÃO PARA A CULTURA DO CAFÉ
}

Dissertação apresentada à Universidade Federal de Viçosa Campus Rio Paranaíba, como parte das exigências do Programa de Pós-Graduação em Agronomia - Produção Vegetal, para obtenção do título de Magister Scientiae.

RIO PARANAÍBA

MINAS GERAIS - BRASIL

2016 
Ficha catalográfica preparada pela Seção de Catalogação e Classificação da Biblioteca UFV - Campus Rio Paranaíba

$\mathrm{T}$

Sousa Júnior, José Márcio de, 1991-

S725d Determinação do indice de volume de pulverização para a

2016 cultura do café : Regulagem e calibração de Pulverizador

Hidropneumático / José Márcio de Sousa Júnior. - Rio

Paranaiba, MG, 2016.

viii, 57f. : il. (algumas color.); $29 \mathrm{~cm}$.

Inclui anexos.

Orientador: Renato Adriane Alves Ruas.

Dissertação (mestrado) - Universidade Federal de Viçosa Campus UFV - Rio Paranaiba.

Inclui bibliografia.

1. Tecnologia de aplicação. 2. Calibração. 3. Café arábica. I. Universidade Federal de Viçosa Campus UFV - Rio Paranaíba. Campus UFV - Rio Paranaiba. Mestrado em

Agronomia-Produção Vegetal (campus CRP). II. Título. 
JOSÉ MÁRCIO DE SOUSA JÚNIOR

\section{DETERMINAÇÃO DO ÍNDICE DE VOLUME DE PULVERIZAÇÃO PARA A CULTURA DO CAFÉ}

Dissertação apresentada à Universidade Federal de Viçosa Campus Rio Paranaíba, como parte das exigências do Programa de Pós-Graduação em Agronomia - Produção Vegetal, para obtenção do título de Magister Scientiae.

APROVADA:

Robson Shigueaki Sasaki

Professor Alberto Carvalho Filho

(Co-orientador)

Professor Renato Adriane Alves Ruas

(Orientador) 


\section{DEDICATÓRIA}

À José Márcio, Teresinha e Camila

Esta vitória também é de vocês. 


\section{AGRADECIMENTOS}

Agradeço, primeiramente, a Deus por ter guiado e iluminado cada passo meu, até que eu chegasse aqui.

Agradeço aos meus pais, José Márcio e Teresinha, e à minha irmã Camila Andrade, por toda ajuda, companheirismo e incentivo em todas as fases dessa minha formação pessoal e profissional. E a minha namorada Jéssika Cristina, pelo companheirismo, carinho e amor.

Agradeço ao meu orientador, Renato Adriane Alves Ruas, pela oportunidade, paciência, empenho e profissionalismo.

Aos colegas do GRUPO DE PESQUISAS EM MECANIZAÇÃO AGRÍCOLA, Carlos Diego, Carlos Roberto, Douglas Dyonathan, Guilherme Andrade, João Godinho, Lucas Caixeta, Luiz Otávio, Wilian Sudan e Marília Almeida, pelo companheirismo e pelo auxílio na realização dos trabalhos de campo.

Aos Professores Cláudio Pagotto Ronchi, Alberto Carvalho Filho, Vinícius Ribeiro Faria, Ézio Marques da Silva e Flávio Lemes Fernandes pela colaboração, sugestões e correções que engradeceram este trabalho.

Aos técnicos Bruno Henrique Rocha, Paulo Henrique da Cunha, Danilo Henrique Pereira e Helber Dumont Pereira pelo companheirismo e pelo auxílio na realização dos trabalhos de campo.

Agradeço aos meus amigos e colegas de mestrado, pela amizade e alegrias vividas.

À Universidade Federal de Viçosa - Campus Rio Paranaíba pela oportunidade de cursar o mestrado e a CAPES pelo auxílio financeiro.

E à todos que contribuíram de alguma forma para a conclusão desse trabalho. 


\section{BIOGRAFIA}

JOSÉ MÁRCIO DE SOUSA JÚNIOR, filho de José Márcio de Sousa e Teresinha Maria de Andrade Sousa, nasceu na cidade de Carmo do Paranaíba, Minas Gerais, em 14 de janeiro de 1991.

No dia 12 de dezembro de 2008, concluiu curso técnico profissionalizante em Agropecuária pelo Centro Federal de Educação Tecnológica de Bambuí (CEFET-Bambuí), Minas Gerais, Brasil.

No dia 14 de agosto de 2014, graduou-se em Engenharia Agronômica pela Universidade Federal de Viçosa - Campus Rio Paranaíba (UFV-CRP), Minas Gerais, Brasil.

No dia 04 de agosto do mesmo ano, iniciou o curso de Mestrado no Programa de PósGraduação em Agronomia - Produção Vegetal pela Universidade Federal de Viçosa - Campus Rio Paranaíba, submetendo-se à defesa de dissertação em 30 de junho de 2016. 


\section{SUMÁRIO}

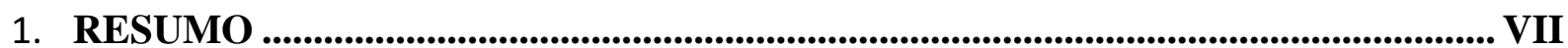

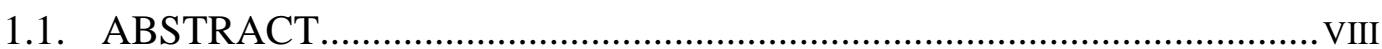

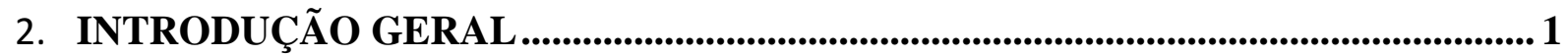

2.1. REFERÊNCIAS......................................................................... 3

3. $1^{\circ}$ ARTIGO: VERTICAL VOLUMETRIC DISTRIBUTION OF AN AXIAL FAN SPRAYER ON THE BREVIPALPUS PHOENICIS CONTROL ...............................5

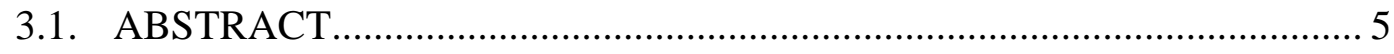

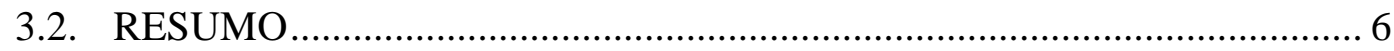

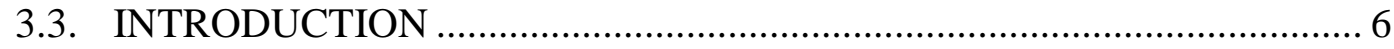

3.4. MATERIAL AND METHODS …........................................................... 8

3.5. RESULTS AND DISCUSSION ........................................................ 13

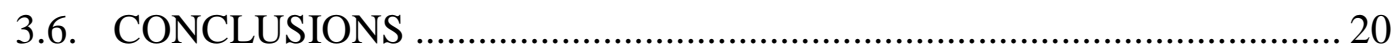

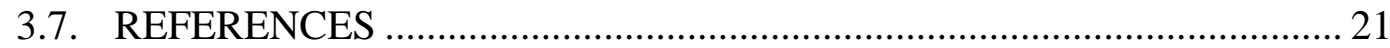

4. $2^{\circ}$ ARTIGO: DETERMINAÇÃO DO ÍNDICE DE VOLUME DE PULVERIZAÇÃO PARA A CULTURA DO CAFÉ (COFFEA ARABICA L.) .......................................... 24

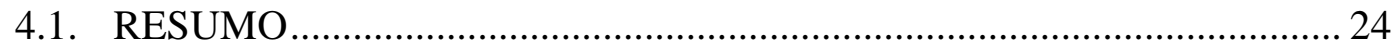

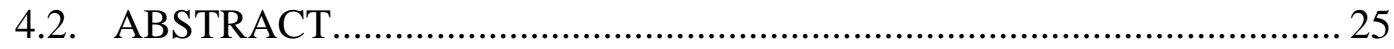

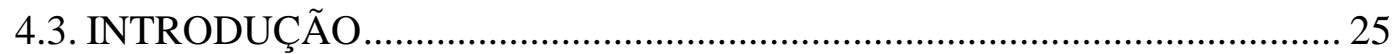

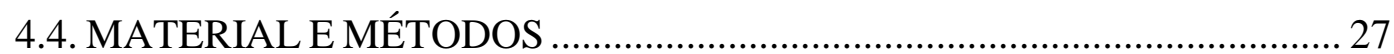

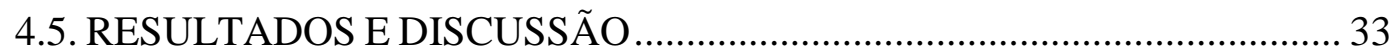

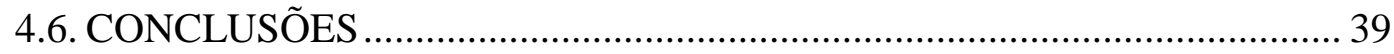

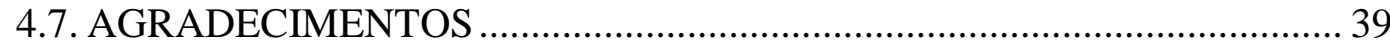

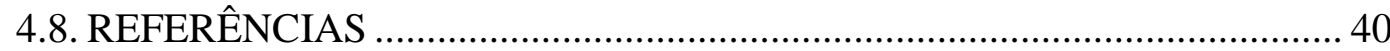

5. $3^{\circ}$ ARTIGO: INFLUÊNCIA DA DENSIDADE FOLIAR NA DISTRIBUIÇÃO DE CALDA NO DOSSEL DO CAFEEIRO (COFFEA ARABICA L.)............................... 42

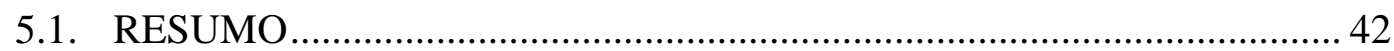

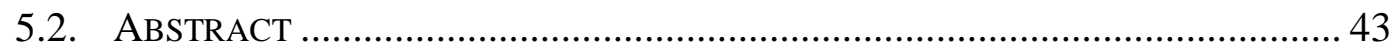

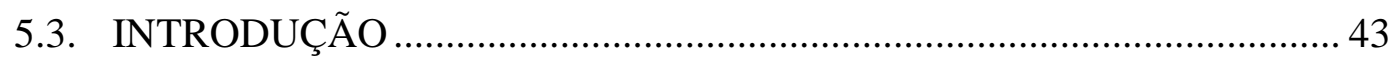

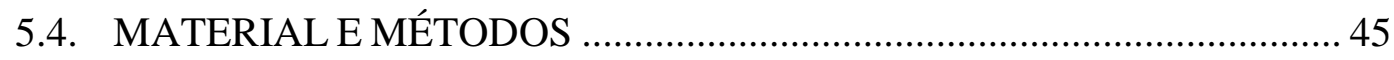




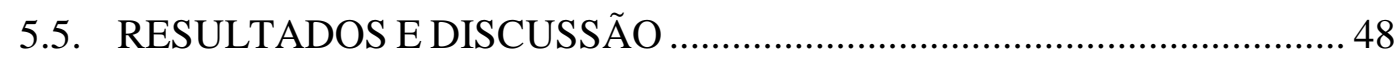

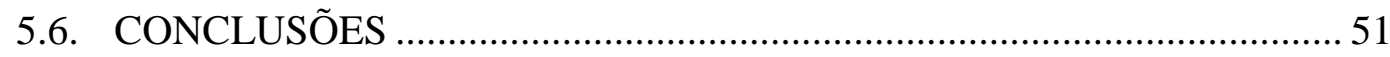

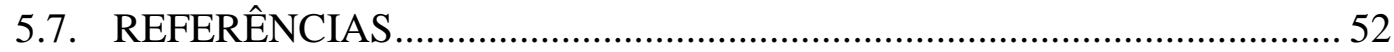

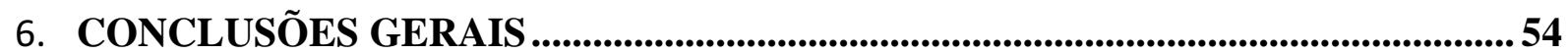

7. ANEXOS 


\section{RESUMO}

SOUSA JÚNIOR, José Márcio de, M.Sc., Universidade Federal de Viçosa, Junho de 2016. Determinação do índice de volume de pulverização para a cultura do café. Orientador: Renato Adriane Alves Ruas. Coorientadores: Alberto Carvalho Filho e Vinícius Ribeiro Faria.

De modo geral, o manejo fitossanitário das lavouras de café é realizado empregandose pulverizadores hidropneumáticos. Assim, a distribuição de calda proporcionada por esses equipamentos deve ser analisada com critério, sob pena de elevar custos de produção e causar contaminação ambiental. Aliado a isto, a calibração por meio do ajuste do volume de calda de acordo como o volume de vegetação, tem-se mostrado uma forma de tornar as aplicações de agrotóxicos mais eficientes. Porém, para adoção deste método para o cafeeiro, ainda é necessário a determinação do Índice volumétrico (IV). Portanto, objetivou-se com este trabalho, analisar e padronizar a distribuição de calda proporcionada pelo pulverizador hidropneumático e utilizá-lo nas aplicações visando a determinação do índice volumétrico de pulverização para cultura do café (Coffea arabica L.). Preliminarmente às aplicações, foi realizada a verificação do coeficiente de variação da distribuição volumétrica vertical do pulverizador hidropneumático equipado com diferentes configurações de pontas no arco de pulverização. Avaliou-se também a influencia da uniformidade de distribuição na eficácia de controle de Brevipalpus phoenicis. Para isso, o pulverizador foi equipado com as configurações que apresentaram maiores uniformidades de distribuição. $\mathrm{Na}$ determinação do IV, foram aplicados cinco volumes de calda (200; 300; 500; 600 e $800 \mathrm{~L} \mathrm{ha}^{-1}$ ) em cinco volumes vegetativos (TRV), em três estádios de desenvolvimento (enchimento, maturação e pós-colheita dos frutos) de forma a verificar tanto o efeito do volume vegetativo quanto o da densidade foliar. A maior uniformidade de distribuição foi proporcionada quando o pulverizador foi equipado na parte inferior com cinco pontas $\mathrm{MAG}_{3,0}$, parte mediana com nove pontas $\mathrm{MAG}_{1,5}$ e parte superior com quatro pontas $\mathrm{MAG}_{3,0}$. No entanto, apesar de se ter uma distribuição mais uniforme, não foi verificada diferença $(\mathrm{p}>0,05)$ entre a porcentagem de incidência de B. phoenicis e as configurações de pontas. Verificou-se que o ajuste das curvas de densidade de gotas de acordo com o IV, em função do estádio de desenvolvimento permite reduzir em até $47 \%$ o volume de calda aplicado. A distribuição dos ramos na planta de forma homogênea proporciona menor variabilidade de distribuição de calda no dossel. Conclui-se que, a maior uniformidade de distribuição de calda não interfere na eficácia de controle de B. phoenicis e que o IV é uma alternativa para se reduzir o volume de calda aplicado em lavouras de café. 


\subsection{ABSTRACT}

SOUSA JÚNIOR, José Márcio de, M.Sc., Universidade Federal de Viçosa, June of 2016. Determination of spray volume index for the coffee culture. Adviser: Renato Adriane Alves Ruas. Co-advisers: Alberto Carvalho Filho and Vinícius Ribeiro Faria.

In general, the plant management of coffee plantations is performed employing hydropneumatic sprayers. Thus, the syrup distribution provided by these devices must be analyzed with discretion, under penalty of increasing production costs and cause environmental contamination. Added to this, the calibration by adjusting the spray volume according to the volume of vegetation, has shown a way to make the most efficient pesticide applications. However, for adopting this method for the coffee, the determination of volume level is still necessary (IV). Therefore, the aim of this study was to analyze and standardize the syrup distribution provided by the hydropneumatic spray and use it in applications in order to determine the volumetric rate of spraying for coffee (Coffea arabica L.). Preliminary applications, verification of vertical volumetric distribution coefficient of variation of hydropneumatic sprayer equipped with different configurations of points in arc spraying was carried out. It also evaluated the influence of distribution uniformity in Brevipalpus phoenicis control effectiveness. For this, the sprayer was equipped with the settings that had greater uniformity of distribution. In determining the IV, they were applied five volumes of syrup (200, 300, 500, 600 and $800 \mathrm{~L} \mathrm{ha}^{-1}$ ) in five vegetative volumes (TRV) in three stages of development (filling, maturation and post-harvest fruit) in order to verify the effect of both vegetative volume and the density of foliage. The more uniform distribution was provided when the spray was equipped at the bottom with five points $\mathrm{MAG}_{3.0}$, median of nine $\mathrm{MAG}_{1.5}$

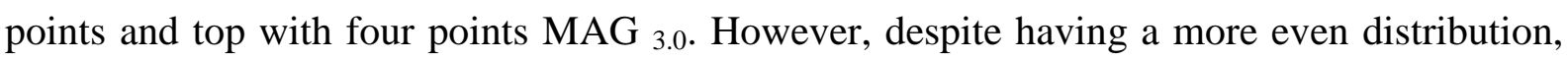
was not observed $(\mathrm{p}>0.05)$ between the percentage of incidence of B. phoenicis and tips settings. It was found that adjusting the density curves drops according to IV, depending on the developmental stage allows to reduce by $47 \%$ the amount of slurry applied. The distribution of branches in homogeneously plant provides less spray distribution variability in the canopy. In conclusion, the highest uniformity of the spray distribution does not interfere with control efficacy of B. phoenicis and the IV is an alternative to reduce the spray volume applied

to coffee plantations. 


\section{INTRODUÇÃO GERAL}

Os cafés produzidos no estado de Minas Gerais, principalmente na região de Cerrado, vêm conquistando mercados cada vez mais exigentes, principalmente, o europeu. Em geral, esses mercados, exigem cafés certificados, pois, normalmente, possuem maior qualidade, devido ao processo de rastreabilidade (UTZ CERTIFIED, 2010). Dentre os critérios para certificação, destaca-se a racionalização do uso de agrotóxicos (REDE DE AGRICULTURA SUSTENTÁVEL, 2014), os quais podem resultar em alguns agravantes para o controle de qualidade como, por exemplo, contaminação ambiental, intoxicação do operador, além do aumento da quantidade de resíduos no café colhido.

Assim, torna-se necessário o emprego correto da tecnologia de aplicação, de modo que o ingrediente ativo seja depositado no alvo no momento adequado, na quantidade certa, com o mínimo de desperdício e contaminação ambiental. Nesse contexto, torna-se muito importante o conhecimento não apenas do produto aplicado, mas também do equipamento utilizado, bem como de suas principais formas de uso.

Em geral, os pulverizadores hidropneumáticos são os mais utilizados nas pulverizações em lavouras de café. Eles apresentam como característica a dupla fragmentação do líquido em gotas. A primeira fragmentação ocorre pela passagem da calda sob pressão pelo orifício da ponta e, a segunda, pela ação do vento produzido por um ventilador de alta vazão. Porém, esta última fragmentação ocorre em menor intensidade, posto que, a corrente de ar produzida, favorecea trajetória das gotas pulverizadas em direção ao alvo, aumentando a penetração e a deposição dos produtos no dossel do cafeeiro (GIL et al., 1996). No entanto, na maioria das vezes, as pulverizações realizadas por esses equipamentos resultam em aplicações ineficientes (HIGASHIBARA et al., 2013). Em geral, são aplicados elevados volumes de calda, no intuito de compensar as perdas e fazer com o produto atinja os alvos que são de difícil acesso.

Os volumes aplicados na lavoura do café variam entre 400 e $800 \mathrm{~L} \mathrm{ha}^{-1}$, independentemente do volume de vegetação (MATIELLO et al., 2010). Com isso, para lavouras mais novas, devido à pouca área foliar, pode resultar em escorrimento superficial, contaminação do solo e de áreas vizinhas em consequência da deriva (MATUO, 1990).

Sendo assim, para reduzir os problemas ocasionados por aplicações com os pulverizadores hidropneumáticos, faz-se necessário a correta realização da regulagem e calibração. Entende-se por regulagem como sendo a verificação e, caso necessário, ajuste de todos os componentes do pulverizador, de forma a produzir gotas de uma determinada classe 
de tamanho e realizar a aplicação a uma determinada taxa. Destaca-se durante essa etapa, a importância da correta seleção e configuração das pontas hidráulicas na barra de pulverização, sendo um fator muito importante para maior uniformidade de distribuição volumétrica ao longo da faixa vertical pulverizada.

A calibração consiste no ajuste do volume de calda aplicado e na quantidade de produto a ser colocado no tanque. A calibração dos pulverizadores hidropneumáticos pode ser realizada de duas formas: Em uma delas, considera-se uma área conhecida, que é obtida pelo espaçamento entre linhas da lavoura, vezes 50 metros a serem percorridos pelo pulverizador, operando na pressão de trabalho e velocidade selecionada. Após a pulverização, mede-se o volume aplicado e extrapola-se o valor encontrado para um hectare. Nessa forma de calibração, considera-se a quantidade de volume aplicado por área de lavoura. Entretanto, o que se objetiva nas pulverizações em cafeeiros é atingir certo volume de vegetação que se encontra disposto na vertical.

Assim, outra possível forma de calibração é adotar metodologia que considere o volume a ser pulverizado em função do volume de vegetação por unidade de área ou "Volume Tree-Row" (TRV). Esse método apresenta bons resultados quando empregado nas calibrações de pulverizadores para aplicações em fruteiras (SUTTON \& UNRATH, 1988; RÜEGG et al, 1999; SIEGFRIED et al., 2007). Em videiras a adoção deste método proporcionou a redução do o uso de pesticidas em até $57 \%$, mantendo a cobertura e penetração taxas semelhantes às de pulverização convencional (GIL et al., 2007). Entretanto, ainda não existem registros na literatura sobre esse tipo de calibração para a lavoura de café.

O ajuste do volume de calda ao volume de vegetação, dentre outros fatores, consiste na determinação do índice volumétrico (IV), que corresponde ao volume de calda necessário para cobrir adequadamente um metro cúbico do dossel. Esse índice é conhecido para algumas fruteiras, como a laranjeira, porém ainda desconhecido para a cultura do café.

O ajuste deste índice apresenta como limitação a variação de volume vegetativo apresentado pela lavoura de café, que se dá em função de diversos fatores, tais como: idade da planta, desfolha decorrente da colheita (SANTINATO et al., 2014), ataque de pragas e doenças (MATIELLO et al., 2010), realização de podas (FERNANDES et al., 2012), variações sazonais que ocorrem em função da disponibilidade hídrica e variação na temperatura (DaMATTA et al., 2007). Essas variações, principalmente ao longo das estações, resultam em alterações na densidade foliar (BERNI et al., 1999), tendo influencia direta na eficácia das pulverizações, sobre tudo, na penetração, distribuição e deposição da calda (SILVA et al., 2014). 
Portanto, acredita-se que a calibração de pulverizadores hidropneumáticos considerando o volume de calda de acordo com o volume de vegetação aumente a eficiência de pulverizações na cultura do café. Com isso, a perdas e a contaminação ambiental são reduzidas, resultando em maior competitividade e sustentabilidade da produção.

\subsection{REFERÊNCIAS}

BERNI, R.F.; MACHADO, V.O.F.; COSTA, G.R.; BARATA, G.; PAULA, R.S. Avaliação da cobertura de gotas provocadas por diferentes bicos de pulverização na cultura do milho e do feijão. Pesquisa Agropecuária Tropical, Goiânia, v.29, n.1, p.49-52, 1999.

DaMATTA, F.M.; RONCHI, C.P.; MAESTRI, M.; BARROS, R.S. Ecophysiology of coffee growth and production. Brazilian Journal Plant Physiology, Londrina, v.19, n.4, p.485-510, 2007.

FERNANDES, A.L.T.; SANTINATO, F.; SANTINATO, R.; MICHELIM, V. Condução das podas do cafeeiro irrigado por gotejamento cultivado no Cerrado de Minas Gerais. Enciclopédia Biosfera, Goiânia, v.8, n.15, p.110-19, 2012.

GIL, E.; BADIOLA, J.; ARMENGOL, E.; BERNAT, C. Design and verification of a moving equipment for orchard and vineyard sprayer calibration. In: INTERNATIONAL CONFERENCE ON AGRICUltural ENGINEERING, 1996, Madrid. Proceedings... Madrid: European Society of Agricultural Engineers, 1996. 8p.

GIL, E.; ESCOLÀ, A.; ROSELL, J.R.; Planas, S.; Val, L. Variable rate application of plant protection products in vineyard using ultrasonic sensors. Crop Protection, Amsterdan, v.26, p.1287-1297, 2007.

HIGASHIBARA, L.; DUTRA, V.; ABI SAAB, O.J.G.; TAKAHASHI, H.W.; NEVES, C.S.V.J. Turboatomizador e repasse com pistola manual na cobertura de pulverização de agrotóxicos em caquizeiro (Diospyros kaki L.f.). Ciência Rural, Santa Maria, v.43, n.5, p.845-849, 2013.

MATIELLO, J. B.; SANTINATO, R.; GARCIA, A. W. G.; ALMEIDA, S. R.; FERNANDES, D. R. Cultura de café no Brasil: Novo Manual de Recomendações. Rio de Janeiro e Varginha: MAPA/PROCAFÉ, 2010. 542 p.

MATUO, T. Técnica de aplicação de defensivos agrícolas. Jaboticabal: Funep, 1990. 139p. REDE DE AGRICULTURA SUSTENTÁVEL. Norma para obtenção do selo de certificação Rainforest Alliance: Medidas tomadas para obtenção da certificação. Disponível em: 
<http://www.san.ag/biblioteca/docs/SAN-S-1-1.2_Sustainable_Agriculture_Standard.pdf>. Acesso em: 06 de Outubro de 2014.

UTZ CERTIFIED. Certificação de propriedades: cafés certificados. Disponível em: <http://www.utzcertified.org/index.php?pageID=101\&switchlanguage=PT->. Acesso em: 06 de Outubro de 2014.

RÜEGG, J.; VIRET, O.; RAISIGL, U. Adaptation of spray dosage in stone-fruit orchards on the basis of the tree row volume. Bulletin, v.29, p.103-110. 1999.

SANTINATO, F.; SILVA, R.P.; CASSIA, M.T.; SANTINATO, R. Análise quali-quantitativa da operação de colheita mecanizada de café em duas safras. Coffee Science, Lavras, v.9, n.4, p.495-505, 2014

SIEGFRIED, W.; VIRET, O.; HUBER, B.; Wohlhauser, R.. Dosage of plant protection products adapted to leaf area index in viticulture. Crop Protection, Amsterdan, v.26, p.73-82, 2007.

SILVA, B.M.; RUAS, R.A.A.; SICHOCKI, D.; DEZORDI, L.R.; CAIXETA, L.F. Deposição da calda de pulverização aplicada com pontas de jato plano em diferentes partes da planta de soja (Glycine max) e milho (Zea mays). Engenharia na agricultura, v.22, n.1, p.17-24, 2014.

SUTTON, T. B.; UNRATH, C. R. Evaluation of the tree-row-volume model for full season pesticide application on apples. Plant Disease, Madison, v.72, n.7, p.629-632, 1988. 


\section{3. $1^{\circ}$ ARTIGO: Vertical volumetric distribution of an axial fan sprayer on the}

\section{Brevipalpus phoenicis control}

\subsection{ABSTRACT}

\section{(1)}

Spray distribution generated by axial fan sprayer, among other factors, should be critically analyzed, in order to prevent unnecessary costs and environmental contamination. This study aimed at evaluating the effect of the vertical volumetric distribution of an axial fan sprayer on the Brevipalpus phoenicis control efficiency. First, an assay was performed to evaluate the vertical volume distribution uniformity of the the sprayer, assessing different spray nozzles configurations on the spray arcs, sides of the sprayer and spray heights. Afterwards, another experiment was carried out to analyze the relationship between the distribution of Fenpyroximate acaricide applied to Coffea arabica L. and the B. phoenicis control. The treatments were arranged in a $4 \times 2$ factorial +1 additional control, consisting of four spray volumes (200 $\mathrm{L} \mathrm{ha}^{-1}, 400 \mathrm{~L} \mathrm{ha}^{-1}, 600 \mathrm{~L} \mathrm{ha}^{-1}$ and $800 \mathrm{~L}$ ha-1) and two spray nozzles configurations (1: $100 \%$ of $\mathrm{MAG}_{1.5}$ nozzles; 2: upper extension with $5 \mathrm{MAG}_{3.0}$ nozzles, middle extension with $9 \mathrm{MAG}_{1.5}$ nozzles and lower extension with $4 \mathrm{MAG}_{3.0}$ nozzles). Configuration 2 provided the smallest coefficient of variation (28\%). Nozzle configurations had no effect on the incidence of B. phoenicis. The use of nozzles with different flow rates on the spraying arc improves the vertical volumetric distribution uniformity of axial fan sprayers, but does not affect the $B$. phoenicis control efficiency.

KEY-WORDS: Coffea arabica L.; spray nozzles; pesticide application. 


\subsection{RESUMO}

A distribuição de calda proporcionada por pulverizadores hidropneumáticos, dentre

4 outros fatores, deve ser analisada com critério, sob pena de elevar custos de produção e causar

5 contaminação ambiental. Objetivou-se avaliar o efeito da distribuição volumétrica vertical de

6 pulverizador hidropneumático na eficácia de controle de Brevipalpus phoenicis.

7 Primeiramente, realizou-se ensaio visando a avaliar a uniformidade de distribuição

8 volumétrica vertical do pulverizador, considerando-se diferentes configurações de pontas nos

$9 \operatorname{arcos}$ de pulverização, lados e altura de pulverização. Em seguida, realizou-se outro 10 experimento, com o intuito de analisar a relação entre a distribuição do acaricida 11 Fenpiroximato aplicado a lavoura de Coffea arabica L. e o controle de B. phoenicis. Os 12 tratamentos foram dispostos em esquema fatorial $4 \times 2+1$ testemunha adicional, sendo eles: 13 quatro volumes de calda (200 L ha ${ }^{-1}, 400 \mathrm{~L} \mathrm{ha}^{-1}, 600 \mathrm{~L} \mathrm{ha}^{-1}$ e $\left.800 \mathrm{~L} \mathrm{ha}^{-1}\right)$ e duas configurações 14 de pontas (1: $100 \%$ das pontas $\mathrm{MAG}_{1,5} ; 2$ : parte superior com 5 pontas $\mathrm{MAG}_{3,0}$, parte 15 mediana com 9 pontas $\mathrm{MAG}_{1,5}$ e parte inferior com 4 pontas $\mathrm{MAG}_{3,0}$ ). A configuração 2 16 proporcionou o menor coeficiente de variação (28 \%). As configurações de pontas não 17 apresentaram efeito na incidência de B. phoenicis. A utilização de pontas com diferentes vazões no arco de pulverização melhora a uniformidade de distribuição volumétrica vertical dos pulverizadores hidropneumáticos, mas não influencia na eficácia de controle de $B$.

20 phoenicis.

21 PALAVRAS-CHAVE: Coffea arabica L.; pontas de pulverização; aplicação de agrotóxico. 
Coffee production is a very important activity for the Brazilian agribusiness, where

2 coffee is one of the major commodities. Estimated domestic production from the 2015 harvest 3 is 1,878 $\mathrm{t}$ (31.3 million bags) of processed Arabica coffee (Conab 2015).

In order to reach high yields, it is necessary to adopt various technologies, including the application of pesticides via axial fan sprayer. The working principle of this sprayer is

6 based on the fragmentation of pressurized liquid into droplets that are released into a high flow and velocity air stream. The high pressure air stream promotes new fragmentation, carrying the droplets to the plant canopy, even at hard-to-reach targets (Ruas et al. 2015).

However, the airflow produced by axial fan sprayers is usually distributed unevenly along the fan outlet (Rodrigues et al. 2008). This is due to the clockwise spinning of the fan, resulting in a greater airflow from the right side, when compared to the left side (Herrera Prat et al. 2002). Therefore, because the airflow produced by the fan has a direct influence on spray distribution uniformity in the plant canopy (Sotolongo \& Herrera 1986), it is possible that the active principle of the applied product does not reach important targets on the plant, hampering the treatment efficacy.

Another factor that may contribute to reduce the application efficiency is the distance between the sprayer nozzle and the target (Mion et al. 2011). Due to the concavity of the spray arc and plant architecture, nozzles positioned at the extremities of the arc present a greater distance to the target. Because the droplets are carried by the airflow (Sotolongo \& Herrera 1986), as the distance between the sprayer nozzle and target increases, the droplet reaches the leaves with less energy and is therefore more subject to drift, reducing the capacity for penetration and deposition on the plant canopy.

This problem may be minimized with the use of spray nozzles that produce largerdiameter droplets at the extremities of the spray arc. These larger droplets are less subject to drift losses, which may result in increased spray deposition at the positions most distant from 
1 the spray arch (Balan et al. 2006), and consequently increased vertical distribution uniformity

2 of the spray.

However, large droplets may present reduced product penetration capacity in the canopy (Cunha et al. 2005). This can result in reduced control efficiency of certain pests, such as the leprosis mite (Brevipalpus phoenicis), transmitter of the coffee ringspot virus (CoRSV) (Almeida et al. 2012). The control of B. phoenicis can be difficult, because it generally stays in the inner middle and inner lower portions of the coffee plant (Reis et al. 2000). Thus, it is necessary to perform studies to clarify the relationship between the volumetric distribution dynamics provided by axial fan sprayers and efficiency of the pesticide treatments. This study aimed at evaluating the effect of vertical volumetric distribution of an axial fan sprayer on the Brevipalpus phoenicis control efficiency.

\subsection{MATERIAL AND METHODS}

The experiment was divided into two parts: determination of the vertical volumetric distribution uniformity of the axial fan sprayer and analysis of the relationship between distribution of acaricides on coffee plants and the control efficiency. In the first part of the experiment, evaluations of the vertical volumetric distribution uniformity were performed in Rio Paranaíba (19¹3'0.90”S and 46²0’36.16”W), Minas

Gerais State, Brazil, in 2015, . A completely randomized design was employed in a 3 x 2 x 2 factorial, consisting of: three configurations of the spray arc nozzles (Configuration 1:100\% of the $\mathrm{MAG}_{1.5}$ nozzles; Configuration 2: lower extension with $9 \mathrm{MAG}_{1.5}$ nozzles and upper extension with $9 \mathrm{MAG}_{3.0}$ nozzles; Configuration 3: upper extension with $5 \mathrm{MAG}_{3.0}$ nozzles, middle extension with $9 \mathrm{MAG}_{1.5}$ nozzles and lower extension with $4 \mathrm{MAG}_{3.0}$ nozzles); both sides of the spray extension (right and left) and two collection heights of the sprayed liquid 
1 (0-1.6 and 1.6-3.2 m), with four replications, totaling 48 experimental units. The nozzles

2 Magno Jet $^{\circledR}$ (MAG) 1.5 and 3.0 have flow rates of 0.56 and $1.13 \mathrm{~L} \mathrm{~min}^{-1}$, respectively, with a 3 pressure of $300 \mathrm{kPa}$.

A vertical collector was constructed consisting of four sections measuring $1 \mathrm{~m}$ long and $2 \mathrm{~m}$ wide in order to collect the sprayed liquid at heights up to $4 \mathrm{~m}$. Each session 6 consisted of 10 channels of galvanized steel bent into a "V" shape, spaced at $0.10 \mathrm{~m}$. The base of the test apparatus was constructed with a $2 \%$ horizontal inclination for fluid flow to one of the channel extremities, to which silicon hoses with a diameter of $0.01 \mathrm{~m}$ were connected. The ends of these hoses were in turn placed in two liter polyethylene bottles to collect the volume deposited in each of the channels.

A tractor pulled Arbus Modelo 2000 TP VA da Jacto ${ }^{\circledR}$ sprayer was used, with a tank capacity of 2,000 L. The sprayer was equipped with a piston pump model JP-190 rated for flow rates up to $190 \mathrm{~L} \mathrm{~min}^{-1}$ and a radial fan that generated an airflow of $19 \mathrm{~m}^{3} \mathrm{~s}^{-1}$. It has a double arch with 36 spray nozzles (18 left and 18 right) individually adjustable, thus allowing various flow configurations from the nozzles. The tractor used was a Valtra ${ }^{\circledR}$ model BF75 4x2 (TDA), whose power at 2,300 rpm is $53 \mathrm{~kW}$ and maximum torque at $1,400 \mathrm{rpm}$ is 260 N.m. The sprayer was regulated and calibrated by the conventional method for a water application 18 volume of $500 \mathrm{~L} \mathrm{ha}^{-1}$.

During application of the treatments, the distance between the sprayer and vertical collector was $1.9 \mathrm{~m}$ (considering spacing between rows of $3.8 \mathrm{~m}$, commonly adopted in 21 Cerrado coffee production) and operating for 60 seconds. The liquid volume from each of the 2240 collection recipients was measured in a graduated cylinder. The average temperature during the evaluations was $20{ }^{\circ} \mathrm{C}$, average relative humidity was $61 \%$ and average wind speed was $5 \mathrm{~km} \mathrm{~h}^{-1}$. 
The distribution profile was determined and its uniformity was estimated with the

2 coefficient of variation $(\mathrm{CV})$ for vertical volume on the left and right sides of the sprayer,

3 considering the sprayer height of $3.2 \mathrm{~m}$ (average height of coffee plants in the region). Data

was subjected to analysis of variance and means were compared by the Tukey test at $5 \%$.

Subsequently, the airflow produced by the fan acting on each spray nozzles was estimated. For this purpose the air velocity was measured using a digital anemometer Instrutherm ${ }^{\circledR}$ model AD-250, with a resolution of $0.10 \mathrm{~m} \mathrm{~s}^{-1}$, positioned parallel to each point at a distance of $0.10 \mathrm{~m}$, on both sides of the fan. From the total air outlet area parallel to the extensions on the right and left side, the area of each section was determined. This allowed estimation of the airflow on each of the 36 spray nozzles (Equation 01).

$$
q=a \times \omega
$$

where: $q=$ air flow $\left(\mathrm{m}^{3} \mathrm{~s}^{-1}\right) ; a=$ areas of the section at which the air velocity was measured $\left(\mathrm{m}^{2}\right)$ and $\omega=$ velocity at each point $\left(\mathrm{m} \mathrm{s}^{-1}\right)$.

The second part of the experiment, which consisted of verifying the effect of the vertical volumetric distribution of acaricide applied with the hydropneumatic sprayer on $B$. phoenicis control efficiency was performed on a plot with ten years old Coffea arábica L. cultivar Catucaí Amarelo, at a farm in Carmo do Paranaiba, Minas Gerais State, Brazil. The farm is located at the geographic coordinates $18^{\circ} 59^{\prime} 30^{\prime \prime} \mathrm{S}$ and $46^{\circ} 19^{\prime} 01^{\prime \prime} \mathrm{W}$, in the Cerrado Mineiro region, with an average altitude of 1,050 $\mathrm{m}$ and climate defined as Cwa according to the Köppen classification. The plot was implemented with spacing between plants and rows of $0.6 \mathrm{~m}$ and $3.8 \mathrm{~m}$, respectively. The plants had an average height of $3 \mathrm{~m}$.

The experiment was conducted in a randomized block design and the treatments were arranged in a $4 \times 2+1$ factorial as follows: four spray volumes $\left(200 \mathrm{~L} \mathrm{ha}^{-1}, 400 \mathrm{~L} \mathrm{ha}^{-1}, 600 \mathrm{~L}\right.$ $\mathrm{ha}^{-1}$ and $800 \mathrm{~L} \mathrm{ha}^{-1}$ ) and two spray nozzle configurations on the spraying arc (Configuration 1:100 \% of the $\mathrm{MAG}_{1.5}$ nozzles; Configuration 3: upper extension with $5 \mathrm{MAG}_{3.0}$ nozzles, 
1 middle extension with $9 \mathrm{MAG}_{1.5}$ nozzles and lower extension with $4 \mathrm{MAG}_{3.0}$ nozzles), plus

2 one additional control and four replications, totaling 36 experimental units. The

3 configurations used were those that provided the lowest coefficient of variation for the

4 vertical volumetric distribution in the previous experiment. The control treatment had no 5 acaricide application.

Each block was composed by four coffee rows, each with nine plots consisting of 60 plants. Plots and blocks were spaced by $30 \mathrm{~m}$, thus providing enough space for tractor gear changes in order to alter the velocities in each treatment and minimize the possible effects of 9 drift.

The acaricide used was fenpyroximate (Ortus $50 \mathrm{SC}^{\circledR}$ ), of the chemical group of pyrazoles, at a dose of $1 \mathrm{~L} \mathrm{ha}^{-1}$ of commercial product (C.P). This product acts by contact and ingestion. Together with the acaricide, the adjuvant Master Forth ${ }^{\circledR}$ at a dose of $0.03 \mathrm{~L} \mathrm{ha}^{-1}$, was added to the spray, which is characterized by having the effect of a surfactant and thickener. Spraying was carried out with the same sprayer used in the first experiment. However, it was pulled and driven by a New Holland ${ }^{\circledR}$ tractor, model TT 3880, whose power at 2,500 $\mathrm{rpm}$ is $44.1 \mathrm{~kW}$. The tractor had a maximum torque at 1,500 rpm of $200 \mathrm{Nm}$. The sprayer was previously adjusted and calibrated by adjusting the velocity and pressure distribution for distribution of the appropriate spray volume for each treatment (Table 1). During application, the average temperature was $26{ }^{\circ} \mathrm{C}$, the average relative humidity (RH \%) was 59 and the average wind speed was $3 \mathrm{~km} \mathrm{~h}^{-1}$. 
Table 1. Pressures, velocities and gears utilized by the tractor-axial fan sprayer set seeking to obtain the desired spray volumes

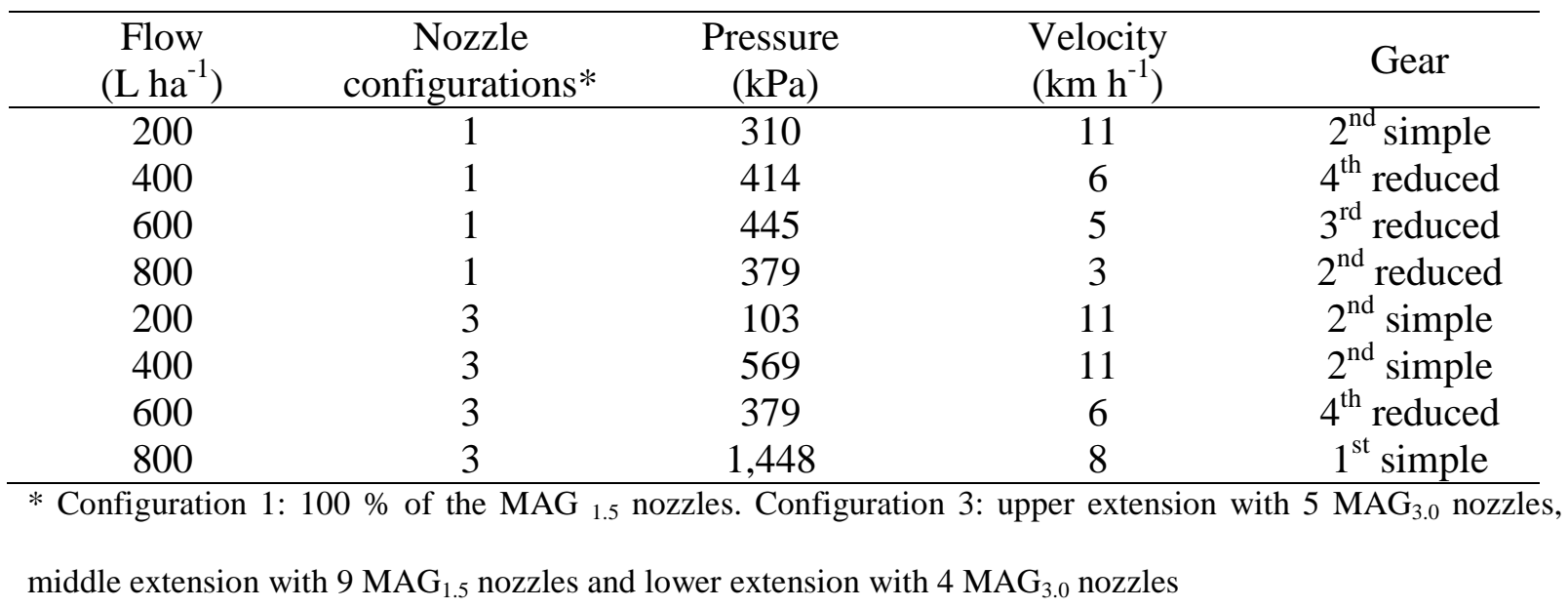

To assess the penetration capacity of droplets into the plant canopy, water sensitive 5 papers were fixed to the orthotropic branch at three heights (bottom, middle and upper third). To control possible effects of the side of passage (right or left side of the extension) at the

7 time of application, the application side was alternated between repetitions. Then the papers 8 were removed, identified and placed in properly labeled packages. In the laboratory the papers 9 were scanned using a calibrated scanner with resolution of 600 DPI and images of spray 10 stains were processed using the CIR 1.5 software (INTA 2002). The variables determined 11 were the percent coverage (PC) (\%) and density of the droplets (DD) (drops cm$)^{-2}$ ).

To estimate the efficiency of B. phoenicis control, an evaluation was performed before 13 application of the treatments and three evaluations after application (24 hours after 14 application-HAA, and 4 and 14 days after application-DAA). For this purpose five plants 15 from the central row of each plot were sampled, and eight branches were sampled from each 16 plant: two internal median branches, two external median branches, two internal lower 17 branches and two external lower branches (Gravena 1992). The occurrence of live $B$. 
1 phoenicis adults or nymphs was verified using a magnifying glass with 40-times resolution

2 capacity, to estimate the percentage of attacked branches.

Data were subjected to analysis of variance $(\mathrm{p} \leq 0.05)$, and when significant the treatment levels were compared with a Tukey test at $5 \%$. In the case of significance of quantitative variables (Spray volumes) a regression analysis was performed.

6

\subsection{RESULTS AND DISCUSSION}

No significant difference ( $\mathrm{p}>0.05$ ) was verified in the average $\mathrm{CV}$ of the vertical volumetric distribution for nozzle configurations 2 and 3 on the left and right sides of the spraying arc. However, for configuration 1 the left side of the spray arc resulted in a CV of the vertical volumetric distribution $22 \%$ smaller than the right side (Table 2). This can be attributed to the fact that the drops are carried by the airflow (Sotolongo \& Herrera 1986), and the right side has a higher air flow due to the clockwise spinning direction of the fan (Herrera Prat et al. 2002 and 2013) (Figure 1).

Furthermore, the arc shape and positioning of the nozzles in relation to the position and direction of the fan rotation also influence distribution of the sprayed liquid (Alvarenga et al. 2014). The nozzles located along the lower portion of the arc are positioned at a greater distance from the fan blades, and therefore they are subject to reduced air flow. Additionally, due to the curvature of the air outlet the lower nozzles present a greater distance to the target and are more subject to environmental action, where the spray droplets may be carried by the wind (Alvarenga et al. 2014). This fact can be observed in the treatment in which nozzles were employed that produce larger drops at the bottom of the arc (configuration 03), resulting in an increased distribution uniformity of $47 \%$ in relation to the right side of configuration 01

(Table 2). This may also be indicated by the $\mathrm{CV}$ of the vertical volumetric distribution at the 
1 average height of 0 to $1.6 \mathrm{~m}$, wherein configuration 03 presented CV's 58 and $45 \%$ lower

2 than configurations 1 and 2, respectively.

3
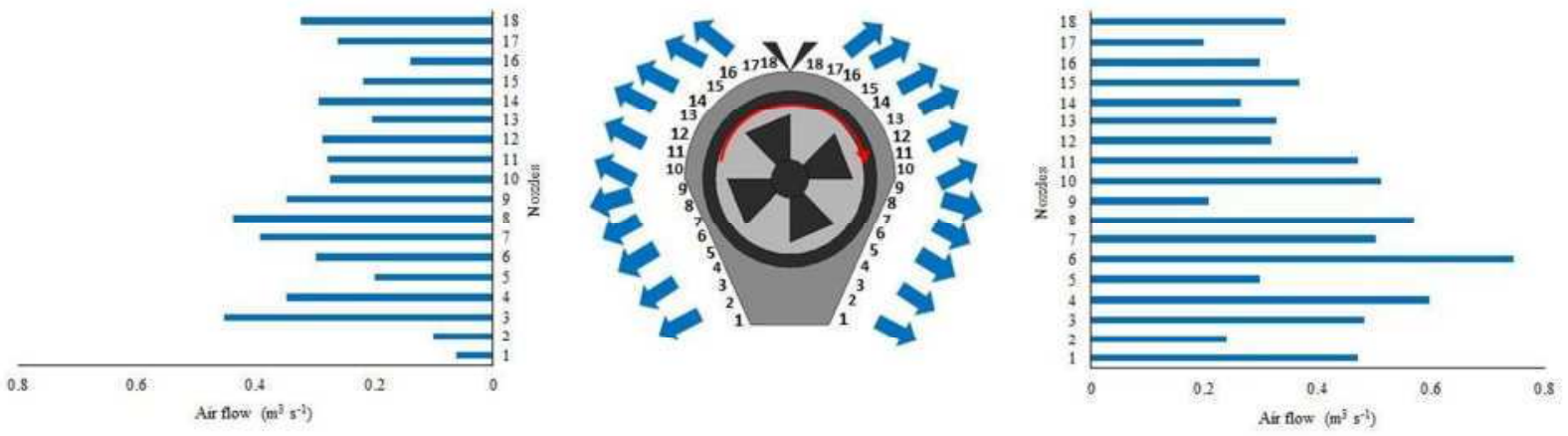

Figure 1. Distribution profile of airflow from the hydraulic nozzles of both sides of the axial

6

7

8

9

fan sprayer.

At the height of 1.6-3.2 $\mathrm{m}$, the CV's of the vertical volumetric distribution of configurations 01,02 , and 03 were $40 \%, 14 \%$ and $51 \%$ higher, respectively, in relation to the height of 0 to $1.6 \mathrm{~m}$. This fact can be attributed to the concavity of the spray arc being more pronounced at this end, resulting in a greater distance between the nozzle and the target and therefore greater losses. Furthermore, configuration 3, at the height of 1.6-3.2 m, presented $\mathrm{CV}$ of the vertical volumetric distribution values $33 \%$ and $26 \%$ lower in relation to configurations 01 and 02, respectively (Table 2). By having nozzles that produced largerdiameter droplets at the ends of the arc, these droplets have a longer useful life and are less carried by the wind, allowing deposition of larger quantities on the targets.

7 
Table 2. Coefficient of variation (CV \%) of the vertical volumetric distribution provided by the right and left sides of the axial fan sprayer, when operated with different hydraulic nozzle configurations at two spraying heights

\begin{tabular}{|c|c|c|c|}
\hline \multirow[b]{2}{*}{ Side } & \multicolumn{3}{|c|}{ Hydraulic nozzle configurations } \\
\hline & $\begin{array}{c}1: \\
18 \mathrm{MAG}_{1.5} \text { nozzles }\end{array}$ & $\begin{array}{c}2: \\
9 \mathrm{MAG}_{1.5} \text { nozzles } \\
\text { and } 9 \mathrm{MAG}_{3.0} \\
\text { nozzles }\end{array}$ & $\begin{array}{c}3: \\
5 \mathrm{MAG}_{3.0} \text { nozzles; } 9 \\
\mathrm{MAG}_{1.5} \text { nozzles; } 4 \\
\mathrm{MAG}_{3.0} \text { nozzles }\end{array}$ \\
\hline Left & $38 \mathrm{bB}$ & $47 \mathrm{aA}$ & $29 \mathrm{bA}$ \\
\hline Right & $49 \mathrm{aA}$ & $46 \mathrm{aA}$ & $26 \mathrm{bA}$ \\
\hline \multicolumn{4}{|c|}{ Height $(\mathrm{m})$} \\
\hline $0-1.6$ & $33 \mathrm{bB}$ & $43 \mathrm{aB}$ & $18 \mathrm{cB}$ \\
\hline $1.6-3.2$ & $55 \mathrm{aA}$ & $50 \mathrm{aA}$ & $37 \mathrm{bA}$ \\
\hline
\end{tabular}

Means followed by the same lower-case letter on the line, or followed by upper-case letter in the column do not differ according to the Tukey test at $5 \%$.

1

For the height of 1.6-3.2 m, the left side of the sprayer extension indicated a CV of the vertical volumetric distribution $20 \%$ greater than the height of $0-1.6 \mathrm{~m}$, which can be attributed to the upward direction of the airflow (Alvarenga et al. 2014) (Table 3). Airflow increases from the lower end to the upper section of the arc, which resulted in deposition of higher spray volumes at the height of 1.6-3.2 $\mathrm{m}$ (Figures 1 and 2).

Table 3. Coefficient of variation (CV \%) of the volumetric distribution provided by the axial fan sprayer, considering the side and two spray heights.

\begin{tabular}{ccc}
\hline & \multicolumn{2}{c}{ Average collection height $(\mathrm{m})$} \\
\cline { 2 - 3 } Side & $0-1.6$ & $1.6-3.2$ \\
\hline Left & $28 \mathrm{bB}$ & $35 \mathrm{aB}$ \\
Right & $48 \mathrm{aA}$ & $46 \mathrm{aA}$ \\
\hline
\end{tabular}

Means followed by the same lower-case letter on the line, or followed by the same upper-case letter in the column do not differ by the Tukey test at $5 \%$. 
(a)

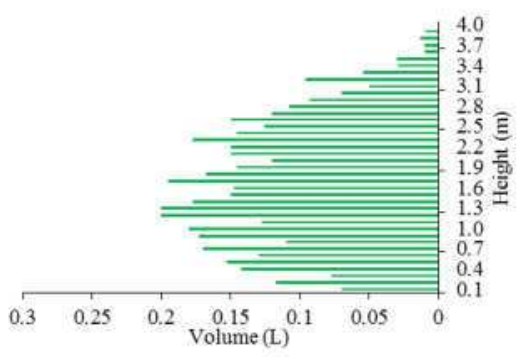

(b)

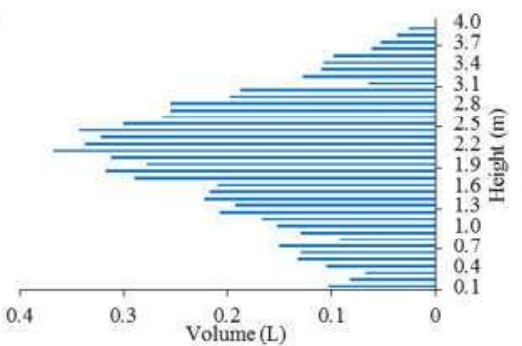

(c)

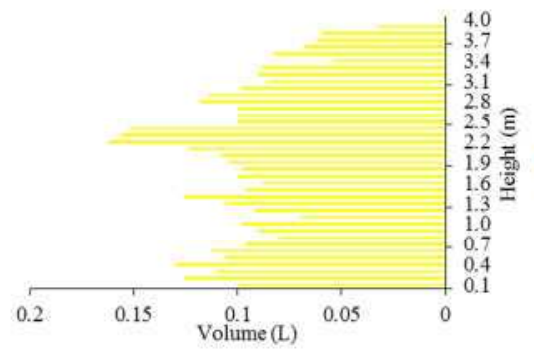

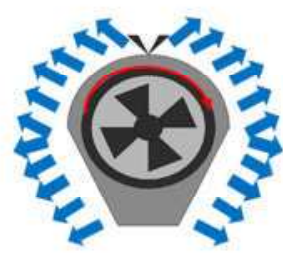
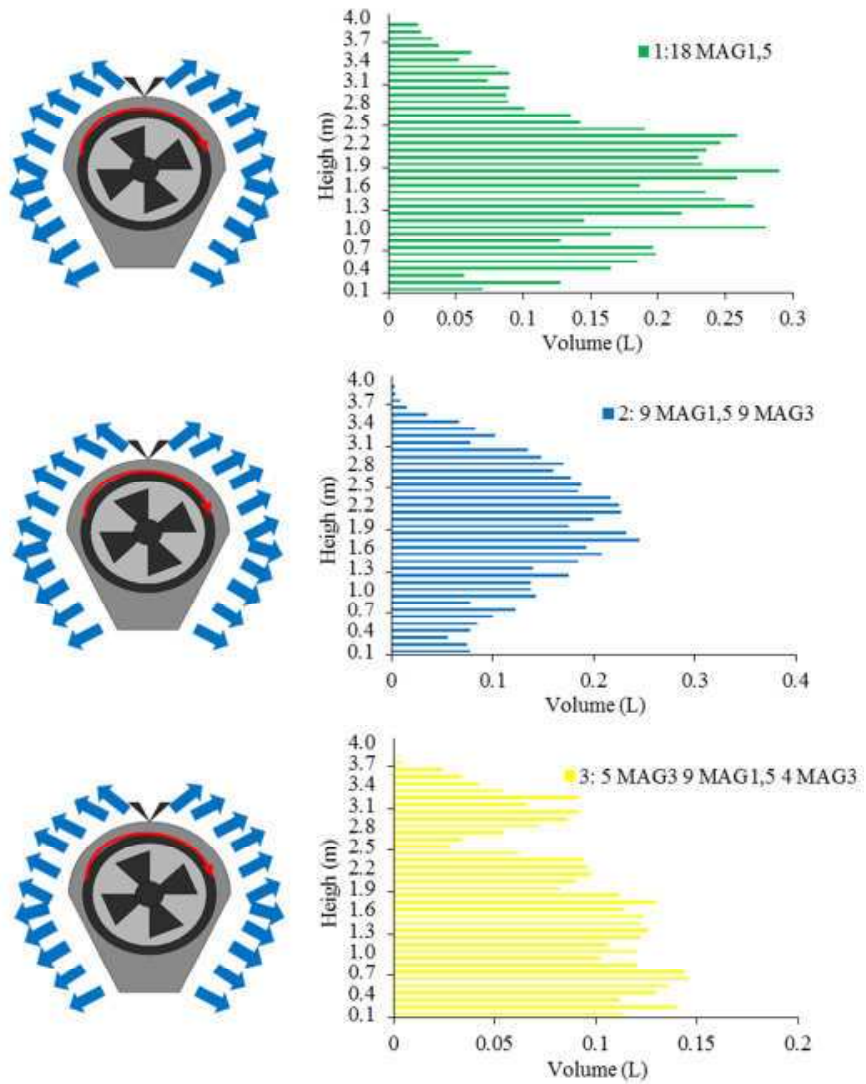

2 Figure 2. Vertical volumetric distribution from the axial fan sprayer on both sides of the spray 3 arcs.

When comparing the two sides of the spray arc, it was observed that, for both heights,

6 the right side resulted in the highest CV of the vertical volumetric distribution (Table 3). This

7 may be associated with the descending rotation direction of the fan combined with the

8 distance from the target. In other words, because of the higher airflow acting on the nozzles,

9 especially number 4 to 11 (right side) (Figure 1), there was a greater liquid directing to the middle and lower portions of the vertical collecting bench (Figure 2). And coupled with this,

11 because the nozzles in the higher portions of the spray were more distant from the vertical 12 collecting bench, there was a lower spray deposition in the higher portions, contributing even 13 more to a higher spray distribution variation on the right side. 
In general, the $\mathrm{CV}$ of the vertical volumetric distribution values encountered were 44

$2 \%, 46 \%$ and $28 \%$ for configurations 1,2 and 3, respectively. These values were $68 \%, 66 \%$

3 and $79 \%$ lower than others previously reported in literature when working with a line of

4 tubes fixed to a vertical post for collection of the sprayed liquid (Alvarenga et al. 2014). This

5 difference may be due to the method for collecting the sprayed liquid, indicating that the best

6 method to do so, in the case of axial fan sprayer, is via a surface that covers all or part of the 7 spray nozzle width.

Regarding the control efficiency of B. phoenicis, it was observed that the period with the greatest reduction in incidence of the pest was 14 DAA, down $64 \%$ in relation to the control. It can also be observe that, even though configuration 03 have provided more uniform distribution compared to configuration 01 , there was no significant difference $(\mathrm{p}>0.05)$ between the percentage incidence of B. phoenicis (Table 4). This shows that the use of higher flow rates at the ends of the arc results in more uniform spray distribution; and although the droplets produced by these nozzles are larger, there was no reduction in the penetration capacity of the active ingredient in the canopy. This is probably due to the airflow and leaf density, which interfere on the control of B. phoenicis in the inner and lower parts of the coffee canopy. The airflow has a direct influence on spray penetration in the canopy. Moreover, because the acaricide was applied post-harvest there was greater defoliation of the Arabica coffee plants (Da Matta et al. 2007), and therefore a lower barrier for penetration and spray deposition. 
Table 4. Percent incidence of B. phoenicis verified after application of acaricide with the axial fan sprayer configured with different spray nozzles.

\begin{tabular}{lccc}
\hline & $24 \mathrm{HAA}$ & $4 \mathrm{DAA}$ & $14 \mathrm{DAA}$ \\
\hline Control & $79 \mathrm{a}$ & $79 \mathrm{a}$ & $86 \mathrm{a}$ \\
Treatments & $54 \mathrm{~b}$ & $50 \mathrm{~b}$ & $31 \mathrm{~b}$ \\
\hline Configurations & & & $29 \mathrm{a}$ \\
\hline $\begin{array}{l}\text { 1: } 18 \mathrm{MAG}_{1.5} \text { nozzles } \\
\text { nozzles; } 4 \mathrm{MAG}_{3} \text { nozzles; } 9 \mathrm{MAG}_{1.5}\end{array}$ & $55 \mathrm{a}$ & $51 \mathrm{a}$ & $33 \mathrm{a}$ \\
\hline
\end{tabular}

Means followed by the same lower-case letter in the column do not differ by the Tukey test at $5 \%$.

Analyzing the spray distribution on the plants, there was no significant difference ( $\mathrm{p}>$

3 0.05) between the nozzles configurations for the response variables droplet density and

4 percent coverage. However, there was a decrease in the percent coverage and droplet density

5 from the upper to the lower positions of the canopy (Table 5). This is attributed to greater

6 overlap of branches of thirds higher than the branches of the lower thirds (Da Matta et al

7 2007). This results in an increase in leaf density and, therefore, reduces the penetration of the

$8 \quad$ spray those portions of the canopy.

Table 5. Droplet density (DD) and percent coverage (PC) obtained in the upper, middle and lower portions of the coffee plant from the axial fan sprayer, operating with different spray nozzle configurations.

\begin{tabular}{lcc}
\hline \multicolumn{1}{c}{ Configurations } & DD $\left(\right.$ drops $\left.\mathrm{cm}^{-2}\right)$ & PC $(\%)$ \\
\cline { 2 - 3 } & & \\
\hline $1: 18 \mathrm{MAG}_{1.5}$ & $370 \mathrm{a}$ & $10 \mathrm{a}$ \\
$3: 5 \mathrm{MAG}_{3} 9 \mathrm{MAG}_{1.5} 4 \mathrm{MAG}_{3}$ & $344 \mathrm{a}$ & $8 \mathrm{a}$ \\
\hline Position in the canopy & & \\
\hline Upper & $450 \mathrm{a}$ & $13 \mathrm{a}$ \\
Middle & $361 \mathrm{~b}$ & $9 \mathrm{~b}$ \\
Lower & $260 \mathrm{c}$ & $6 \mathrm{c}$ \\
\hline
\end{tabular}

Means followed by the same lower-case letter in the column do not differ by the Tukey test at $5 \%$. 
1 immediate effect of the active ingredient in question was low. Moreover, the maximum flow

2 rate utilized may not have been sufficient, considering that the active ingredients require high 3 target coverage since it acts by contact.

At 4 DAA the flow rates of $200 \mathrm{~L} \mathrm{ha}^{-1}$ and $800 \mathrm{~L} \mathrm{ha}^{-1}$ reduced the incidence of $B$.

5 phoenicis by $42 \%$ and $57 \%$ when the droplet density was 190-525 drops $\mathrm{cm}^{-2}$ and coverage

6 was 4 and $16 \%$, respectively. For these flows and values of droplet density and percent 7 coverage, at 14 DAA, $60 \%$ and $78 \%$ pest incidence reductions were verified (Figure 3).

8 Based on these data an inverse relationship was observed between droplet density and coverage with pest incidence. Thus, it can be inferred that droplet density and coverage percentage should be considered as a basis for selecting the proper flow rate, especially when considering the reduced size of some targets, such as the mite (Fernandes et al. 2010). In the lower portions of the coffee plant, where the smaller droplet density and percent coverage are commonly deposited, present thehighest incidence of this pest was observed (Reis et al. 2000). Thus, it is important to increase deposition in these places, because more droplets $\left(\right.$ drops $\mathrm{cm}^{-2}$ ) and increased coverage implies greater and better distribution of the active ingredient, resulting in more effective control. This is especially true when using active ingredients that act by contact and ingestion.

However, new technologies that increase the droplet density and coverage by increasing spray volume may result in increased application costs and, water consumption. Thus, a possible alternative would be to estimate the spray volumes needed to adequately cover a determined plant volume in a given canopy density condition, which as seen in this study, has a direct influence can increase droplet density and percent coverage. Especially in the lower canopy portions of the coffee plants. $85 \%$, a coverage of $\sim 40 \%$ is necessary (Fernandes et al. 2005). However, considering the 
1 maximum reduction of this plague obtained in the present work, which was $78 \%$ when

2 employing a flow of $800 \mathrm{~L} \mathrm{ha}^{-1}$ (14 DAA), increasing control to $87 \%$ would require a spray

3 volume 2.5 times greater (applying the equations of incidence and percent coverage (Figure

4 3b). In other words, for only a $9 \%$ increase in control, an additional 1,200 L ha ${ }^{-1}$ of product 5 are needed.

6

(a) $\begin{aligned} & \text { Incidence } 4 \text { dias APA } \\ & y=-0.0246 x^{2}+62.685^{* *}\end{aligned}$

$\triangle$ Incidence 14 dias APA $R^{2}=0.9994 \quad 0.13^{* *} y=0.5615 x^{* *}+76.54$
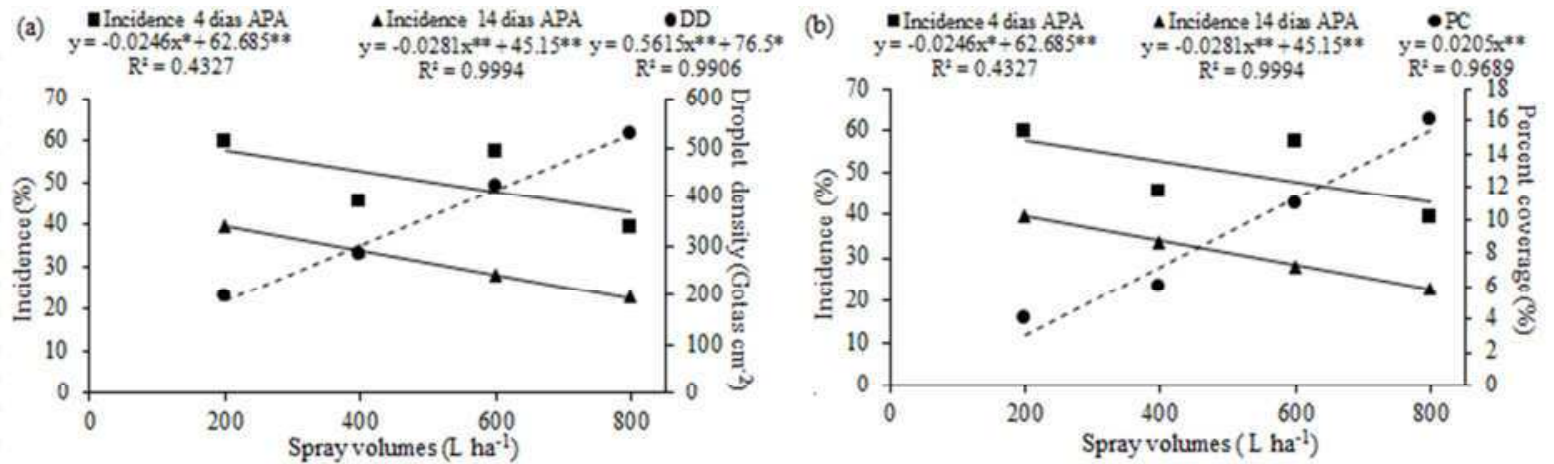

8 Figure 3. Incidence (\%) of B. phoenicis observed at 4 and 14 days after application of the

9 acaricide in function of the droplet density (DD) (a) and percent coverage (PC) (b) , resulting from application of different spray volumes. * and $* *$ Significant by the $t$ test at $5 \%$ and $1 \%$,

11 respectively.

12

Despite the fact that the increase in the uniformity of vertical volumetric distribution did not increase the B. phoenicis control efficiency, it was verified, in this study, that the use of spray nozzles which produce larger diameter droplets at the ends of the spray arc, as was the case of configuration 3 , results in a more uniform spray distribution, with lower loss risks.

\subsection{CONCLUSIONS}

1. The use of spray nozzles with higher flow rates at the ends of the spray arc increase vertical

21 volumetric distribution uniformity of the hydropneumatic sprayer. 
1 2. Increased vertical volumetric distribution uniformity of the hydropneumatic sprayer does

2 not influence the $B$. phoenicis control efficiency.

3 3. The combination of nozzles with greater flow on the spray arc does not hinder control of $B$.

4 phoenicis in the inner parts of the coffee canopy.

5 4. The increase in droplet density and target coverage contribute to greater control of $B$. 6 phoenicis.

\subsection{REFERENCES}

ALMEIDA, J. E. M. et al. Análise temporal e controle da mancha anular e do ácaro vetor do Coffee ringspot virus. Pesquisa Agropecuária Brasileira, v. 47, n. 7, p. 913-919, 2012.

ALVARENGA, C. B. et al. Air and liquid volumetric distribution in vertical in a hydropneumatic sprayer. Applied Research \& Agrotecnology, v. 7, n. 1, p. 71-79, 2014.

BALAN, M. G.; ABI SAAB, O. J. G.; SASAKI, E. H. Distribuição da calda na cultura da Videira por turboatomizador com diferentes configurações de pontas. Ciência Rural, v. 36, n. 3, p. 731-38, 2006.

COMPANHIA NACIONAL DE ABASTECIMENTO. Acompanhamento da safra brasileira: produção agrícola de café. $2015 . \quad$ Available at: <http://www.conab.gov.br/OlalaCMS/uploads/arquivos/15_09_30_11_17_06_boletim_cafe_s etembro_2015.pdf>. Acess on: 05 Nov. 2015.

CUNHA, J. P. A. R. et al. Deposição e deriva de calda fungicida aplicada em feijoeiro, em função de bico de pulverização e de volume de calda. Revista Brasileira de Engenharia Agrícola e Ambiental, v. 9, n. 1, p. 133-138, 2005.

DA MATTA, F. M. et al. Ecophysiology of coffee growth and production. Brazilian Journal of Plant Physiology, v. 19, n. 4, p. 485-510, 2007. 
1 FERNANDES, A. P.; FERREIRA, M. C.; MARTINELli, N. M. Mortalidade do ácaro

2 Brevipalpus phoenicis em função da cobertura de pulverização de acaricidas, com e sem

3 adjuvantes, em mudas de café. Revista de Agricultura, v. 80, n. 2, p. 173-187, 2005.

4 FERNANDES, A. P.; FERREIRA, M. C.; OLIVEIRA, C. A. L. Eficiência de diferentes

5 ramais de pulverização e volumes de calda no controle de Brevipalpus phoenicis na cultura do

6 café. Revista Brasileira de Entomologia, v. 54, n. 1, p. 130-135, 2010.

7 GRAVENA, S. Manejo ecológico de pragas do cafeeiro. Jaboticabal: Cemip-Funep, 1992.

8 HERRERA PRAT, M. et al. Analisis de la velocidad del aire en la corriente de las

9 asperjadoras utilizadas en frutales. Ciencias Técnicas Agropecuarias, v. 11, n. 2, p. 53-58, 102002.

11 HERRERA PRAT, M. I.; DE LA FIGAL, G. C; DE LA CUEVAS, H. M. Análisis de la 12 aerodinámica del ventilador del pulverizador ASS-800 empleado en frutales. Ciencias

Técnicas Agropecuarias, v. 22, n. 4, p. 15-19, 2013.

INSTITUTO NACIONAL DE TECNOLOGÍA AGROPECUARIA (INTA). $T \& C C I R$ : conteo y tipificación de impactos de pulverización. Versión 1.5. Buenos Aires: INTA, 2002. MION, R. L. et al. Uso de mesa vertical como parâmetro para regulagens de turboatomizadores. Engenharia Agrícola, v. 31, n. 2, p. 352-358, 2011.

REIS, P. R. et al. Spatial distribution of Brevipalpus phoenicis (Geijskes) (Acari:Tenuipalpidae) in coffee plants (Coffea arabica L.). Anais da Sociedade Entomológica do Brasil, v. 29, n. 1, p. 177-183, 2000.

RODRIGUES, G. J. et al. Características do fluxo de ar de um pulverizador hidropneumático para aplicação de agroquímicos em plantas arbustivas. Engenharia na Agricultura, v. 16, n. 2, p. 199-207, 2008.

RUAS, R. A. A. et al. Proposta de método para a inspeção em pulverizadores hidropneumáticos. Coffee Science, v. 10, n. 1, p. 76-82, 2015. 
1 SOTOLONGO, I.; HERRERA, M. Caracterización de la corriente de aire de una asperjadora

2 de ventilador en el plano horizontal. Ciencias Técnicas Agropecuarias, v. 0, n. 1, p. 1-12, 31986.

4

5

6

7

8

9

10

11

12

13

14

15

16

17

18

19

20

21

22

23

24

25 


\section{4. $2^{\circ}$ ARTIGO: DETERMINAÇÃO DO ÍNDICE DE VOLUME DE PULVERIZAÇÃO PARA A CULTURA DO CAFÉ (Coffea arabica L.)}

RESUMO: O ajuste do volume de calda de acordo como o volume de vegetação tem-se mostrado uma forma de tornar as aplicações de agrotóxicos mais eficientes. Porém, para adoção deste método para o cafeeiro, ainda é necessário a determinação do Índice volumétrico. Assim, objetivou-se determinar do índice volumétrico de pulverização para a cultura do café (Coffea arabica L.). Os tratamentos foram dispostos em blocos seguindo fatorial (5 x 5), sendo cinco volumes de calda (200; 300; 500; 600 e $\left.800 \mathrm{~L} \mathrm{ha}^{-1}\right)$ e cinco volumes vegetativos (TRV), com quatro repetições. Realizou-se a avaliação de densidade foliar previamente às aplicações dos tratamentos em três estádios de desenvolvimento (enchimento, maturação e pós-colheita dos frutos). Analisou-se a deposição de calda (DEP), densidade de gotas (DEN), diâmetro mediano volumétrico (DMV) das gotas e amplitude relativa (SPAN) do espectro de gotas. Os volumes de calda aplicados foram convertidos em índice volumétrico (IV). Não houve interação ente TRV e volume de calda $(\mathrm{p}>0,05)$ para as variáveis respostas DEP e DEN. Na avaliação realizada durante o estádio de maturação, a densidade foliar foi 29 \% superior à época de pós-colheita e a DEP máxima obtida foi de 0,74 $\mu \mathrm{L} \mathrm{cm}^{-2}$. O DMV médio obtido foi de $217 \mu \mathrm{m}$ e o SPAN de 1,1. O ajuste da curva de DEN de acordo com o IV permitiu estimar uma redução em até $47 \%$ do volume de calda aplicado. Concluiu-se que o ajuste do IV de acordo com as variações de densidades foliares permite reduzir o volume de calda aplicado em lavouras de café.

Termos para indexação: Calibração de pulverizador, Tree-Row-Volume, volume de calda. 

DETERMINATION OF SPRAY VOLUME INDEX FOR CULTURE OF COFFEE (Coffea arabica L.)

\subsection{ABSTRACT}

ABSTRACT: The adjustment of the spray volume according to the volume of vegetation has been shown a way to make the most efficient pesticide applications. However, for the adoption of this method for the coffee, the determination of the volume index is still needed. Thus, the aim was to determine the volumetric rate of spraying for coffee (Coffea arabica L.). The treatments were arranged in blocks following factorial (5 x 5), five spray volumes (200, 300, 500, 600 and $800 \mathrm{~L} \mathrm{ha}^{-1}$ ) and five vegetative volume (TRV) with four replications. We conducted the evaluation of leaf density prior to the application of treatments in three development stages (filling, maturation and post-harvest fruit). We analyzed the spray deposition (SD), density of the droplets (DD), the volumetric median diameter (VMD) of the droplets and relative amplitude (SPAN) of droplet spectrum. The applied spray volumes were converted to volumetric index (VI). There was no interaction being TRV and water volume ( $>$ > 0.05) for the variables SD and DD answers. In the evaluation performed during the maturation stage, leaf density was $29 \%$ higher at the time of post-harvest and the maximum SD obtained was $0.74 \mathrm{~cm} 2 \mathrm{uL}$. The VMD medium obtained was $217 \mathrm{~m}$ and the span 1,1 . The adjustment of the curve DD according VI allowed to estimate a reduction of up to $47 \%$ of the spray volume applied. It was concluded that the VI set according to the changes in leaf density reduces the spray volume applied to coffee plantations.

Index terms: Sprayer calibration, Tree-Row-Volume, spray volume.

\subsection{INTRODUÇÃO}


Os cafés produzidos no estado de Minas Gerais, principalmente na região do Cerrado,

52 possuem boa aceitação por mercados externos, inclusive, aqueles que exigem cafés certificados. Dentre os critérios para certificação, destaca-se a racionalização do uso de agrotóxicos (REDE DE AGRICULTURA SUSTENTÁVEL, 2014). Assim, torna-se

necessário o emprego correto da tecnologia de aplicação de modo que o ingrediente ativo seja depositado no alvo no momento adequado, na quantidade certa, com o mínimo de desperdício e contaminação ambiental (MATTHEWS, 2008).

Neste contexto, é importante que o equipamento utilizado seja submetido a uma correta regulagem e calibração (RUAS et al., 2015). O termo regulagem refere-se à verificação e a realização de ajustes gerais nos componentes do pulverizador. Uma correta regulagem faz com que sejam produzidas gotas de uma determinada classe de tamanho, proporcionando a aplicação do volume desejado. Já a definição de calibração é o ajuste do volume de calda aplicado e a determinação da quantidade de produto a ser colocado no tanque (ANDEF, 2004).

Pulverizadores hidropneumáticos são os equipamentos mais utilizados nas pulverizações em lavouras de café. A calibração desses equipamentos pode ser realizada de duas formas: em uma delas, verifica-se se o volume que está sendo pulverizado em uma área conhecida que, geralmente é determinada pelo deslocamento do conjunto por $50 \mathrm{~m}$, vezes o espaçamento entre linhas, extrapolando-se em seguida o valor encontrado para um hectare. Nessa forma de calibração, considera-se a quantidade de volume aplicado por área de lavoura, independentemente do volume de vegetação. O que pode causar excesso de líquido pulverizado principalmente em lavouras mais novas, devido à pouca área foliar, resultando em escorrimento superficial, contaminação do solo, fitotoxicidade e aumento dos custos de produção (MATUO, 1990). 
Uma segunda forma de calibração dos pulverizadores hidropneumáticos é a adoção do

76 "Tree-Row-Volume" (TRV) ou volume de calda por volume de vegetação, por unidade de área plantada. A adoção deste método em aplicações em videiras possibilita redução do uso de agrotóxicos em até 57\% (GIL et al., 2007). Na cultura do tomate essa redução pode chegar à $30 \%$ (SANCHEZ-HERMOSILLA et al., 2013). Em citrus o emprego deste método tem apresentado boa eficiência e eficácia de controle de doenças fúngicas (HABERLE; AGOSTINI; ACUÑA, 2011; SCAPIN et al., 2015).

A calibração pelo TRV requer o conhecimento do índice volumétrico (IV), que corresponde ao volume de calda necessário para cobrir adequadamente um metro cúbico do dossel. Esse índice é conhecido para algumas fruteiras, porém, ainda desconhecido para o cafeeiro. Posto que, para que seja feita sua determinação, alguns fatores relativos ao volume vegetativo devem ser considerados. São eles: idade das plantas, desfolha decorrente da colheita (SANTINATO et al., 2014), ataque de pragas e doenças (MATIELLO et al., 2010) e variações sazonais que ocorrem em função da disponibilidade hídrica e variação na temperatura (DA MATTA et al., 2007). Tais variações podem ocorrer ao longo das estações do ano e resultam em alterações na densidade foliar (BERNI et al., 1999), tendo influência direta na eficácia das pulverizações, principalmente, na penetração, distribuição e deposição da calda (SILVA et al., 2014).

Portanto, acredita-se que a determinação do IV para o cafeeiro possa contribuir para melhorias das aplicações de agrotóxicos. Para tanto, é necessário estudar aplicações de volumes de calda capazes de promoverem deposições adequadas em diferentes estádios de desenvolvimento da lavoura. Dessa forma, objetivou-se com este trabalho, determinar o índice de volume de pulverização para cultura do café (Coffea arabica L.). 

localizada em $19^{\circ} 13^{\prime} 0.90^{\prime}$ S, longitude 46²0’36.16” O, na região do Cerrado Mineiro. Altitude média de 906 m e clima Cwa de acordo com a classificação de Köppen Geiger.

105 em esquema fatorial 5 x 5, sendo: cinco volumes de calda $\left(200 ; 300 ; 500 ; 600\right.$ e $\left.800 \mathrm{~L} \mathrm{ha}^{-1}\right)$ e

106 cinco volumes vegetativos (TRV-1; TRV-2; TRV-3; TRV-4; TRV-5), com quatro repetições.

107 Em cada um desses talhões selecionou-se uma linha de plantas, na qual foram demarcadas as 108 parcelas compostas pelos cinco volumes de calda. As parcelas foram espaçadas $20 \mathrm{~m}$ entre si 109 e formadas por 20 plantas, tendo como base a linha de aplicação.

110 As avaliações foram realizadas isoladamente em três estádios de desenvolvimento do 111 cafeeiro (enchimento de grãos, maturação e pós-colheita dos frutos) e consistiram na análise 112 da deposição de calda e da capacidade de penetração das gotas de pulverização no dossel das 113 plantas. A partir de dados de capacidade de penetração das gotas e de deposição de calda de 114 pulverização, foi ajustado o índice volumétrico (IV) para cada um dos estádios de 115 desenvolvimento.

116 A determinação do TRV foi feita em 20 plantas em áreas previamente selecionadas, 117 medindo-se a altura, a largura (no terço inferior, superior e mediano do dossel) e o 118 espaçamento entre linhas (Equação 1).

$\mathrm{TRV}=\frac{\mathrm{H} \times \mathrm{L} \times 10000}{\mathrm{D}}$ Equação (01)

Em que:

$\mathrm{TRV}=$ volume vegetativo $\left(\mathrm{m}^{3} \mathrm{ha}^{-1}\right)$; $\mathrm{H}=$ altura das plantas $(\mathrm{m})$ $\mathrm{L}=$ largura média dos terços das plantas $(\mathrm{m})$; $\mathrm{D}=$ distância entre linhas da cultura (m) 
Foram realizadas análises de densidade foliar em cada um dos estádios. Para tanto,

126 utilizou-se o delineamento inteiramente casualizado, com os tratamentos dispostos em

127

128

129 130 TRV-5). esquema de parcela subdividida, com três repetições. As parcelas constituíram-se pelos três estádios de desenvolvimento do cafeeiro (enchimento de grãos, maturação e pós-colheita dos frutos) e as subparcelas pelos cinco volumes vegetativos (TRV-1; TRV-2; TRV-3; TRV-4;

Nos meses de Março, Julho e Dezembro de 2015, que corresponderam aos três estádios de desenvolvimento, foi realizada a derriça manual e pesagem de todas as folhas de três plantas em cada talhão. Assim, de posse das massas médias das plantas, volume vegetativo $\left(\mathrm{m}^{3} \mathrm{ha}^{-1}\right)$ e conhecendo-se a população de plantas por hectare, foi determinada a densidade foliar de cada um dos talhões (Equação 02) (Tabela 1). Ao final destas avaliações, os dados foram tabulados e submetidos à análise de variância $(\mathrm{P} \leq 0,05)$, e, quando pertinente, procedeu-se a realização do teste de Tukey à 5\% de probabilidade.

$$
\mathrm{D}=\frac{\mathrm{M}}{(\mathrm{TRV} / \mathrm{N})}
$$

Em que:

$$
\mathrm{D}=\text { densidade foliar }\left(\mathrm{kg} \mathrm{m}^{-3} \text { planta }^{-1}\right)
$$

$\mathrm{M}=$ massa médias de folhas por planta $(\mathrm{kg})$;

$$
\mathrm{TRV}=\text { volume vegetativo }\left(\mathrm{m}^{3} \mathrm{ha}^{-1}\right) ;
$$

$\mathrm{N}=$ número de plantas por hectare (plantas ha ${ }^{-1}$ ). 
Tabela 1- Caracterização dos talhões utilizados no experimento

\begin{tabular}{cccccc}
\hline \multirow{2}{*}{ Talhão } & \multicolumn{5}{c}{ TRV $\left(\mathrm{m}^{3} \mathrm{ha}^{-1}\right)$} \\
\cline { 2 - 5 } & $\begin{array}{c}\text { Idade } \\
\text { (Anos) }\end{array}$ & Março & Julho & Dezembro & $\begin{array}{c}\text { No plantas } \\
\left(\text { plantas ha }{ }^{-1}\right)\end{array}$ \\
\hline 1 (TRV-1) & 2 & 2943 & 4146 & 5005 & 4386 \\
$2($ TRV-2) & 3 & 4559 & 6055 & 7252 & 4386 \\
$3($ TRV-3) & 6 & 7661 & 7747 & 7847 & 4386 \\
$4($ TRV-4) & 9 & 12102 & 12522 & 12879 & 5263 \\
$5($ TRV-5) & 29 & 18746 & 19207 & 19214 & 2500 \\
\hline
\end{tabular}

149

Para realização das avaliações de penetração de gotas e deposição de calda de pulverização em cada época de aplicação, foi empregado o pulverizador hidropneumático tratorizado Arbus Modelo 2000 TP VA da Jacto ${ }^{\circledR}$, com capacidade para 2.000 L de calda no tanque, dotado de uma bomba de pistão modelo JP-190 com vazão de até $190 \mathrm{~L} \mathrm{~min}^{-1}$ e ventilador radial com vazão de ar de $19 \mathrm{~m}^{3} \mathrm{~s}^{-1}$. Ele possuía também arco de pulverização duplo com 36 pontas Magno Jet ${ }^{\circledR}$ (MAG) 1,5 e 3,0 que possuem vazões de 0,56 e 1,13 $\mathrm{L} \mathrm{min}^{-1}$ na pressão de $300 \mathrm{kPa}$, respectivamente, distribuídas da seguinte forma: parte inferior com cinco pontas $\mathrm{MAG}_{3,0}$, parte mediana com nove pontas $\mathrm{MAG}_{1,5}$ e parte superior com quatro pontas $\mathrm{MAG}_{3,0}$.

O trator utilizado foi o NEW HOLLAND ${ }^{\circledR}$ modelo TT 3880 , cuja potência a 2.500 rpm. é de 44,1 kW e torque máximo a $1.500 \mathrm{rpm}$. de $200 \mathrm{Nm}$. O pulverizador foi previamente regulado e calibrado ajustando-se a velocidade e a pressão para distribuição do volume de calda adequado a cada tratamento. As aplicações foram realizadas com as seguintes condições climáticas: temperatura média foi de $24{ }^{\circ} \mathrm{C}$, umidade relativa média (UR \%) de 61 e velocidade do vento média de $4 \mathrm{~km} \mathrm{~h}^{-1}$.

Para verificar a deposição de calda de pulverização no dossel do cafeeiro, adicionou-se à calda de pulverização, o corante azul brilhante (solução aquosa traçadora), na dose de 3000 
$167 \mathrm{mg} \mathrm{L} \mathrm{L}^{-1}$. Subsequente à aplicação, coletou-se oito folhas em nove pontos (três terços e três 168 profundidades). Nesses pontos, as folhas foram coletadas da seguinte forma: lado da 169 pulverização (segundo par de folhas a partir da extremidade do ramo situado no lado da 170 pulverização); centro da planta (primeiro par de folhas a partir do ramo ortotrópico no interior 171 no dossel das plantas), lado oposto (primeiro par de folhas a partir da extremidade do ramo 172 situado no lado oposto à pulverização).

173 Após coletadas, as folhas foram acondicionadas em sacos plásticos, lavadas em $20 \mathrm{~mL}$

174 de água destilada e agitadas manualmente por trinta segundos. Posteriormente, as folhas 175 foram retiradas da solução resultante e armazenadas em sacos plásticos devidamente 176 identificados de acordo com o ponto amostral e com a repetição. Em laboratório, a solução foi 177 analisada em espectrofotômetro, modelo EVOLUTION-300, utilizando-se comprimento de 178 onda de $625 \mathrm{~nm}$ (SILVA et al., 2014), obtendo-se assim, a concentração do corante em cada 179 amostra. As amostras de folhas foram enxugadas e tiveram sua área $\left(\mathrm{cm}^{2}\right)$ mensurada, 180 utilizado o AREA METER LICOR modelo LI - 3000C. De posse das absorbâncias em 181 concentração do corante e da área foliar do segmento (oito folhas coletadas por ponto) 182 realizou-se determinação da deposição de calda $\left(\mu \mathrm{L} \mathrm{cm}^{-2}\right)$ (LIMBERGER, 2006) (Equação 183 03).

$$
\mathrm{D}=\frac{10^{6} \times \mathrm{V} \times[\text { solução }]}{\mathrm{A} \times[\text { calda }]}
$$
Em que: $\mathrm{D}=$ deposição de calda $\left(\mu \mathrm{L} \mathrm{cm}^{-2}\right)$

$187 \quad \mathrm{~V}=$ volume de água utilizado para lavar as folhas $(\mathrm{L})$;

188 [solução] = concentração do corante na solução de lavagem $\left(\mathrm{mg} \mathrm{L}^{-1}\right)$;

$189 \quad \mathrm{~A}=$ área foliar do segmento $\left(\mathrm{cm}^{2}\right)$; [calda] = concentração do corante na calda de pulverização $\left(\mathrm{mg} \mathrm{L}^{-1}\right)$. 
A avalição da capacidade de penetração das gotas de pulverização no dossel do

192 cafeeiro foi realizada concomitantemente com a avaliação de deposição de calda. Para tanto,

193 fixou-se etiquetas hidrossensíveis no primeiro par de folhas a partir do ramo ortótropico no

194 interior no dossel das plantas (centro da planta) nos três terços das plantas (terço superior,

195 médio e inferior). Após a aplicação, as etiquetas foram removidas, identificadas e

196 acondicionadas em placas de Petri. Posteriormente, tiveram suas imagens digitalizadas

197 utilizando-se escâner calibrado com resolução de 600 DPI para processamento das imagens

198 das manchas de pulverização no software CIR 1.5. Determinando-se em seguida os seguintes

199 parâmetros: amplitude relativa (SPAN), diâmetro mediano volumétrico (DMV) $(\mu \mathrm{m})$ e

200 densidade de gotas (DEN) $\left(\right.$ gotas $\left.\mathrm{cm}^{-2}\right)$.

201 Os dados foram tabulados e extraídos de nove pontos: três terços e três profundidades

202 de coleta das folhas e dos três locais de fixação das etiquetas, os valores médios de deposição

203 de calda e de penetração das gotas de pulverização no dossel do cafeeiro. Os dados foram

204 submetidos à análise de variância $(\mathrm{P} \leq 0,05)$, e, quando pertinente, procedeu-se a realização

205 do teste de Tukey à 5\% de probabilidade. Em caso de significância da variável quantitativa

206 volume de calda, foi realizada a análise de regressão.

207 Para estimar o índice volumétrico (IV) foram utilizados os dados de deposição de 208 calda $\left(\mu \mathrm{L} \mathrm{cm} \mathrm{cm}^{-2}\right.$ ) e densidade de gotas (DEN) (gotas $\mathrm{cm}^{-2}$ ), proporcionadas pelos cinco 209 volumes de calda (Equação 04). Possibilitando-se assim, com base nas recomendações feitas 210 por fabricantes de agrotóxicos, verificar a densidade de gotas adequadas para uma 211 determinada aplicação e o IV correspondente.

$$
\mathrm{IV}=\frac{\mathrm{Q} \times 1000}{\mathrm{TRV}}
$$

214 IV= índice de volume de pulverização $\left(\mathrm{L} 1000 \mathrm{~m}^{3} \mathrm{ha}^{-1}\right)$;

$215 \quad \mathrm{Q}=$ volume de calda $\left(\mathrm{L} \mathrm{ha}^{-1}\right)$; 
$\mathrm{TRV}=$ volume de vegetação $\left(\mathrm{m}^{3} \mathrm{ha}^{-1}\right)$.

Não houve interação entre estádio e TRV (p > 0,05) para a variável resposta densidade

221 foliar. Porém, analisando-se isoladamente o fator época, verificou-se que, no estádio de maturação a densidade foliar foi 29 \% superior ao de pós-colheita. Já entre os estádios de póscolheita e enchimento dos frutos não foi verificada diferença ( $p>0,05)$ (Tabela 2). A menor densidade foliar no estádio de pós-colheita, pode ser atribuída a dois fatores principais: ação mecânica de desfolha provocada pela ação das hastes da colhedora (SANTINATO et al., 2014) e restrição hídrica (DA MATTA et al., 2007).

Tabela 2- Densidades foliares obtidas em cada estádio de desenvolvimento do cafeeiro avaliado e em cada TRV

\begin{tabular}{cc}
\hline Estádio & Densidade foliar $\left(\mathrm{kg} \mathrm{m}^{-3}\right.$ planta $\left.^{-1}\right)$ \\
\hline Maturação & $2,1 \mathrm{a}$ \\
Pós-colheita & $1,5 \mathrm{~b}$ \\
Enchimento & $2,0 \mathrm{ab}$ \\
\hline TRV & \\
\hline 1 & $2,7 \mathrm{a}$ \\
2 & $1,6 \mathrm{~b}$ \\
3 & $2,0 \mathrm{~b}$ \\
4 & $1,7 \mathrm{~b}$ \\
5 & $0,7 \mathrm{c}$
\end{tabular}

Médias seguidas de mesma letra minúscula na coluna não diferem entre si pelo teste de Tukey a 5\% de probabilidade. 
apresentou densidades foliares 74, 56, 65 e $59 \%$ inferiores ao TRV-1, TRV-2, TRV-3, TRV-

232 4, respectivamente (Tabela 2). Isso indica que, nem sempre o maior TRV implica em maior 233 densidade foliar. O que pode ser explicado pelo fato de as plantas jovens, estarem em pleno 234 crescimento e desenvolvimento vegetativo (Tabela 1). Isso pôde ser comprovado pelo 235 acréscimo de $29 \%$ no TRV do estádio de maturação para o de pós-colheita e, de $17 \%$, da 236 pós-colheita para enchimento dos frutos (Tabela 1), provavelmente, devido a formação e 237 desenvolvimento das folhas ocorrer concomitantemente ao desenvolvimento dos ramos 238 plagiotrópicos (RONCHI; DA MATTA, 2007).

239 Não houve interação ente TRV e volume de calda ( $p>0,05)$, dentro de cada estádio de 240 desenvolvimento do cafeeiro, para as variáveis respostas DEP e DEN. Analisando-se os 241 efeitos simples do fator TRV, verificou-se que, na avaliação realizada na maturação dos 242 frutos, a DEP e DEN foi igual ( $\mathrm{p}>0$,05) no TRV-1 e TRV-5 (Tabela 3). Apesar de relatos 243 científicos constatarem que a densidade foliar influencia diretamente na penetração e 244 deposição da calda (SILVA et al., 2014), a densidade do TRV-1 foi 74 \% inferior a do TRV245 5. Isso pode ser explicado pelo fato do TRV-5 ser mais velho (Tabela 1) e apresentar maior 246 sobreposição dos ramos e folhas dos terços inferiores pelos terços superiores (DA MATTA et 247 al., 2007), formando uma barreira à penetração e deposição de calda nesses pontos. 
Tabela 3- Médias de TRV dentro de cada estádio de desenvolvimento do cafeeiro, para as variáveis respostas deposição de calda (DEP) e densidade de gotas (DEN)

\begin{tabular}{|c|c|c|}
\hline \multicolumn{3}{|c|}{ Enchimento } \\
\hline TRV & $\operatorname{DEP}\left(\mu \mathrm{L} \mathrm{cm}^{-2}\right)$ & DEN (Gotas $\left.\mathrm{cm}^{-2}\right)$ \\
\hline 1 & $0,3 \mathrm{ab}$ & $106,3 \mathrm{~b}$ \\
\hline 2 & $0,3 \mathrm{ab}$ & $103,2 \mathrm{~b}$ \\
\hline 3 & $0,4 \mathrm{a}$ & $133,3 \mathrm{ab}$ \\
\hline 4 & $0,2 \mathrm{c}$ & $103,6 \mathrm{~b}$ \\
\hline 5 & $0,2 \mathrm{c}$ & $156,6 \mathrm{a}$ \\
\hline $\mathrm{CV}$ & 29,5 & 36,2 \\
\hline \multicolumn{3}{|c|}{ Maturação } \\
\hline 1 & $0,5 \mathrm{a}$ & $117,3 \mathrm{ab}$ \\
\hline 2 & $0,3 \mathrm{c}$ & $86,6 \mathrm{~b}$ \\
\hline 3 & $0,4 \mathrm{~b}$ & $134,4 \mathrm{ab}$ \\
\hline 4 & $0,4 \mathrm{~b}$ & $164,4 \mathrm{a}$ \\
\hline 5 & $0,5 \mathrm{a}$ & $128,4 \mathrm{ab}$ \\
\hline $\mathrm{CV}$ & 22,7 & 46,3 \\
\hline \multicolumn{3}{|c|}{ Pós-colheita } \\
\hline 1 & $0,6 \mathrm{ab}$ & $194,2 \mathrm{a}$ \\
\hline 2 & $0,6 \mathrm{ab}$ & 181,9 a \\
\hline 3 & $0,3 \mathrm{c}$ & $125,5 \mathrm{~b}$ \\
\hline 4 & $0,7 \mathrm{a}$ & $158,2 \mathrm{ab}$ \\
\hline 5 & $0,5 \mathrm{~b}$ & $116,4 \mathrm{~b}$ \\
\hline $\mathrm{CV}$ & 18,3 & 32,1 \\
\hline
\end{tabular}

Médias seguidas de mesma letra minúscula na coluna não diferem entre si pelo teste de Tukey a $5 \%$ de probabilidade.

Ainda para estádio de maturação, o TRV-2 apresentou médias de DEP e DEN 25 e 47

$258 \%$ inferiores ao TRV-4 (Tabela 3). Tal fato pode ser atribuído ao dossel destas plantas estarem

259 mais desenvolvidos, formando um renque, proporcionando maior interceptação das gotas.

260 Devido ao fato de as plantas mais jovens apresentam menor diâmetro do dossel, 261 consequentemente, elas estão situadas a maior distância da saída das pontas de pulverização. 
262 Em função disso, as gotas pulverizadas se tornam mais sujeitas à perdas, podendo volatilizar 263 ou serem carreadas pelo vento, ocasionando menor deposição (ALVARENGA et al., 2014). No estádio de pós-colheita, o TRV-3 proporcionou DEP 50, 50, 57 e $40 \%$ inferior ao TRV-1, 2, 4 e 5, e DEN 35 e $31 \%$ inferior ao TRV-1 e 2 (Tabela 3). Isso pode ser atribuído à desfolha proveniente da colheita ter sido menos acentuada neste talhão em relação aos 267 demais. Tendo-se assim, maior massa foliar, consequentemente, menor penetração e 268 deposição de calda no interior do dossel. Na avaliação realizada no período de enchimento 269 dos grãos, a DEN do TRV- 5 foi 32, 34 e $34 \%$ superior ao TRV-1, 2 e 4, respectivamente

270 (Tabela 3). Isto possivelmente ocorreu devido às plantas dos TRV-1, 2 e 4 terem apresentado 271 maior desenvolvimento vegetativo no final do período seco e chegando ao período de 272 enchimento dos frutos com maior intensidade de enfolhamento, resultando em menor 273 penetração das gotas no interior do dossel do cafeeiro. De acordo com as médias de SPAN, observa-se que os espectros de gotas apresentam 275 boa homogeneidade. Principalmente, por se tratar de pulverização hidráulica que, em geral, 276 formam gotas com tamanhos desuniformes (CUNHA; TEIXEIRA; FERNANDES, 2007) 277 (Tabela 4). São considerados homogêneos os espectros de gotas com valores de SPAN 278 próximos a zero (CUNHA et al., 2004). O DMV médio para cada um dos talhões, nos três 279 estádios avaliados, foi de 223, 226, 213, 184 e $238 \mu \mathrm{m}$, os quais podem ser considerados 280 médios (ASAE, S-572) (Tabela 4). Valores de DMV aliado a boa uniformidade de espectro de 281 gotas (SPAN) proporcionam em geral uma pulverização mais segura, uma vez que, gotas 282 muito pequenas são facilmente perdidas por deriva e gotas excessivamente grandes 283 promovem baixa cobertura do alvo (CUNHA et al., 2004). 
Tabela 4- Médias de amplitude relativa (SPAN) e diâmetro mediano volumétrico (DMV) dos espectros de gotas para cada IV, dentro dos estádios de desenvolvimento do cafeeiro avaliados

\begin{tabular}{|c|c|c|c|c|c|c|c|c|c|c|c|}
\hline \multirow[b]{2}{*}{ Estádio } & \multirow[b]{2}{*}{ IV } & \multicolumn{2}{|c|}{ TRV-1 } & \multicolumn{2}{|c|}{ TRV-2 } & \multicolumn{2}{|c|}{ TRV-3 } & \multicolumn{2}{|c|}{ TRV-4 } & \multicolumn{2}{|c|}{ TRV-5 } \\
\hline & & SPAN & $\begin{array}{l}\text { DMV } \\
(\mu \mathrm{m})\end{array}$ & SPAN & $\begin{array}{l}\text { DMV } \\
(\mu \mathrm{m})\end{array}$ & SPAN & $\begin{array}{l}\text { DMV } \\
(\mu \mathrm{m})\end{array}$ & SPAN & $\begin{array}{l}\text { DMV } \\
(\mu \mathrm{m})\end{array}$ & SPAN & $\begin{array}{l}\text { DMV } \\
(\mu \mathrm{m})\end{array}$ \\
\hline \multirow{5}{*}{ 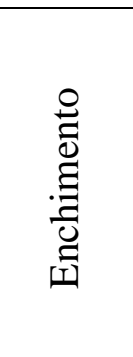 } & 19 & 1.2 & 208 & 1.0 & 225 & 0.9 & 193 & 1.4 & 180 & 1.0 & 266 \\
\hline & 29 & 1.0 & 252 & 0.9 & 228 & 1.1 & 209 & 1.0 & 233 & 1.0 & 263 \\
\hline & 48 & 1.3 & 207 & 1.2 & 202 & 1.2 & 190 & 1.3 & 212 & 1.1 & 195 \\
\hline & 58 & 1.1 & 217 & 1.2 & 213 & 1.0 & 181 & 1.4 & 116 & 1.1 & 284 \\
\hline & 77 & 1.1 & 263 & 1.3 & 248 & 1.0 & 201 & 2.2 & 151 & 1.2 & 205 \\
\hline \multirow{5}{*}{ 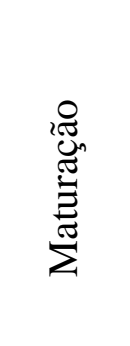 } & 22 & 1.0 & 213 & 0.7 & 234 & 1.0 & 205 & 1.1 & 238 & 1.0 & 275 \\
\hline & 33 & 1.0 & 272 & 0.9 & 240 & 1.0 & 207 & 1.8 & 133 & 1.0 & 261 \\
\hline & 54 & 1.0 & 203 & 0.9 & 221 & 1.1 & 202 & 1.3 & 221 & 1.4 & 255 \\
\hline & 65 & 1.1 & 227 & 1.2 & 215 & 1.1 & 180 & 1.3 & 145 & 1.1 & 191 \\
\hline & 87 & 1.1 & 281 & 1.2 & 260 & 1.1 & 197 & 1.0 & 213 & 1.3 & 213 \\
\hline \multirow{5}{*}{ 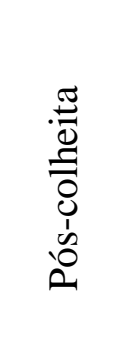 } & 20 & 1.1 & 235 & 1.1 & 224 & 0.9 & 347 & 1.0 & 216 & 1.0 & 247 \\
\hline & 30 & 1.3 & 173 & 1.3 & 224 & 1.0 & 248 & 1.2 & 182 & 1.2 & 241 \\
\hline & 50 & 1.0 & 186 & 1.1 & 242 & 1.0 & 195 & 1.2 & 168 & 1.1 & 281 \\
\hline & 60 & 1.2 & 216 & 1.2 & 197 & 1.1 & 220 & 1.1 & 184 & 1.2 & 225 \\
\hline & 81 & 1.0 & 185 & 1.1 & 210 & 1.1 & 216 & 1.1 & 167 & 1.1 & 173 \\
\hline
\end{tabular}
Analisando-se o fator volume de calda isoladamente, foi possível convertê-lo em IV

287 (Equação 04), ajustando-se, em seguida, equações de regressão para os estádios de maturação, 288 enchimento e pós-colheita para as variáveis respostas DEP e DEN (Figura 1). A DEP mínima 289 e máxima obtida nos estádios de maturação e pós-colheita dos frutos de café, foi de 0,29- 0,63 290 e 0,43-0,74 $\mu \mathrm{L} \mathrm{cm}^{-2}$. Ou seja, no estádio de maturação a DEP mínima e máxima foram 48 e $29115 \%$, respectivamente, superior ao estádio de pós-colheita. Isso se justifica devido ao fato da 292 densidade foliar no estádio de pós-colheita ser menor. Essa menor densidade proporciona 293 menor barreira para deposição de calda no interior do dossel do cafeeiro, contribuindo para o 294 incremento nas médias de deposição de calda neste estádio. 

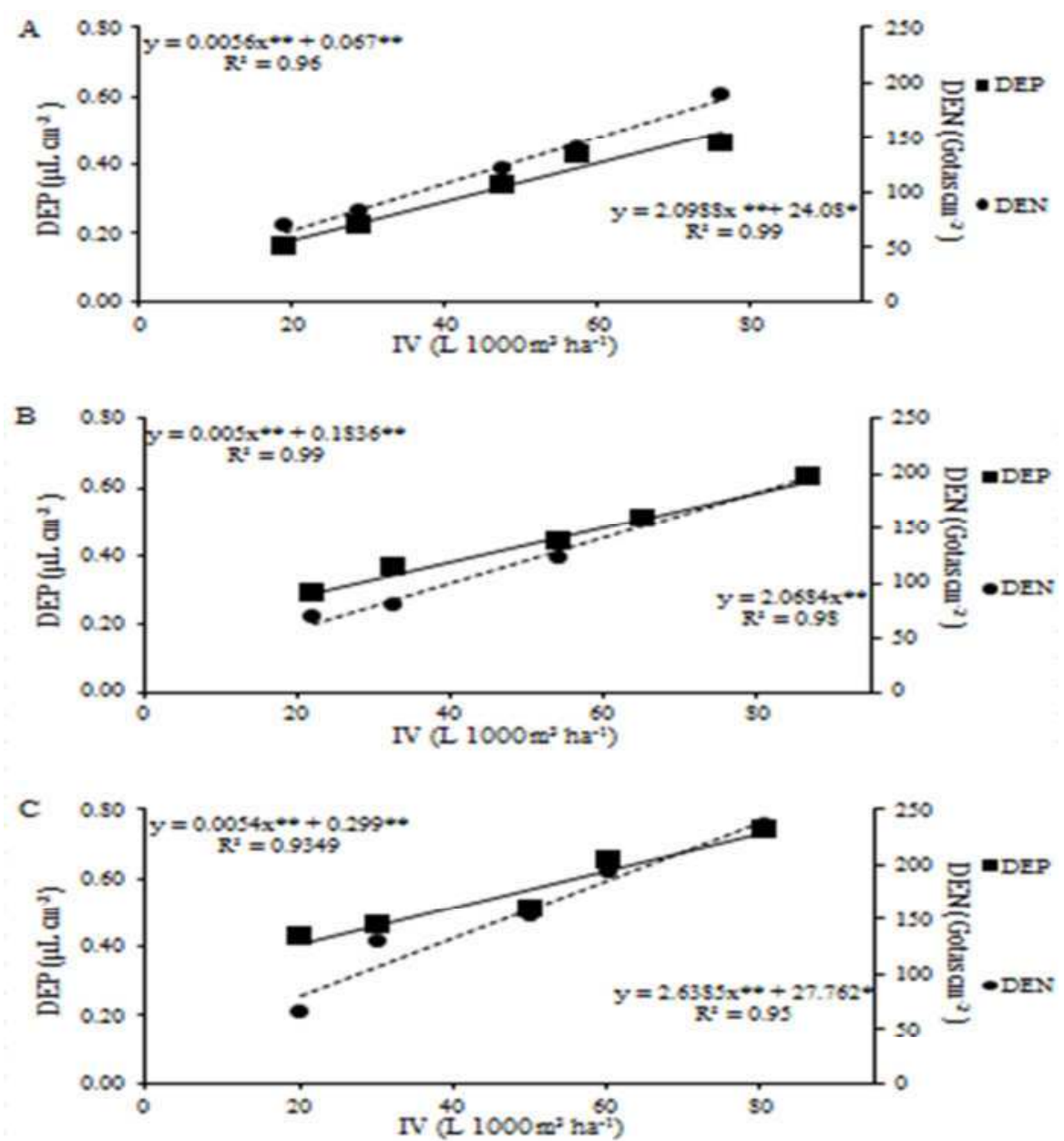

296 Figura 1- Deposição de calda (DEP) e densidade de gotas (DEN), proporcionados pelos cinco 297 volumes de calda aplicados nos cinco volumes de vegetação (TRV) de plantas de Coffea 298 arabica L., nos estádio de enchimento (A), maturação (B) e pós-colheita (C). * e **Significativo pelo teste $\mathrm{t}$ ao nível de 5 e $1 \%$ de probabilidade.

A partir das equações de regressão de IV para cada estádio de desenvolvimento do 302 cafeeiro, considerando-se a variável resposta DEN (Gotas $\mathrm{cm}^{-2}$ ), pode-se inferir o IV 303 adequado de acordo com as recomendações dos fabricantes de agrotóxicos (Figura 1). Para se

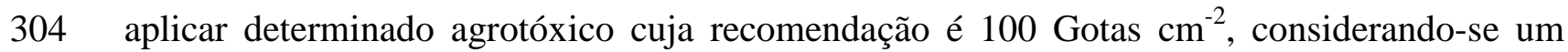
305 talhão com TRV de $3000 \mathrm{~m}^{3}$ ha ${ }^{-1}$, nos estádios de enchimento, maturação, e pós-colheita, 306 seriam necessários para cada estádio, os seguintes volumes de calda: 110,145 e $80 \mathrm{~L} \mathrm{ha}^{-1}$, 307 respectivamente (Equação 05, 06 e 07). 
A partir destes dados verifica-se que, para obtenção de mesma DEN, tem-se redução

309 de volume de calda aplicado no estádio de maturação/ enchimento e maturação/ pós-colheita 310 de 45 e $24 \%$. Ou seja, é possível obter uma economia de água e de agrotóxico de 45 e $24 \%$ a 311 depender do estádio fenológico (pós-colheita e enchimento dos frutos).

$$
\mathrm{Q}=\frac{\left(\frac{\mathrm{DEN}-24,08}{2,0988}\right) \times \mathrm{TRV}}{1000}
$$

$$
\mathrm{Q}=\frac{\left(\frac{\mathrm{DEN}}{2,0684}\right) \times \mathrm{TRV}}{1000}
$$

$$
\mathrm{Q}=\frac{\left(\frac{\mathrm{DEN}-27,762}{2,6385}\right) \times \mathrm{TRV}}{1000}
$$

Em que:

$$
\mathrm{Q}=\text { volume de calda }\left(\mathrm{L} \mathrm{ha}^{-1}\right) \text {; }
$$

$$
\text { TRV= volume de vegetação }\left(\mathrm{m}^{3} \mathrm{ha}^{-1}\right)
$$

\subsection{CONCLUSÕES}

A diminuição da densidade foliar no período de pós-colheita proporciona maior penetração e deposição de calda no dossel do cafeeiro.

A estrutura do dossel de plantas de café mais velhas diminui a deposição e penetração de calda. redução do volume de calda aplicado. 
À Coordenação de Aperfeiçoamento de Pessoal de Nível Superior (Capes), pela concessão da bolsa de mestrado e à Fazenda Transagro S.A., pela disponibilização da área experimental.

\subsection{REFERENCIAS}

ALVARENGA, C.B. et al. Air and liquid volumetric distribution in vertical in a hydropneumatic sprayer. Applied Research \& Agrotecnology, Guarapuava v.7, n.1, p.71-79, 2014.

ANDEF - Associação Nacional de Defesa Vegetal. Manual de tecnologia de aplicação de produtos fitossanitários. Campinas: Linea Criativa, 2004, 52p.

BERNI, R.F. et al. Avaliação da cobertura de gotas provocadas por diferentes bicos de pulverização na cultura do milho e do feijão. Pesquisa Agropecuária Tropical, Goiânia, v.29, n.1, p.49-52, 1999.

CUNHA, J.P.A.R. et al. Espectro de gotas de bicos de pulverização hidráulicos de jato plano e de jato cônico vazio. Pesquisa Agropecuária Brasileira, Brasília, v.39, n.10, p.977-985, 2004.

CUNHA, J.P.A.R.; TEIXEIRA, M.M.; FERNANDES, H.C. Avaliação do espectro de gotas de pontas de pulverização hidráulicas utilizando a técnica da difração do raio laser. Engenharia Agrícola, Jaboticabal, v.27, n.1, p.10-15, 2007.

DA MATTA, F.M. et al. Ecophysiology of coffee growth and production. Brazilian Journal Plant Physiology, Londrina, v.19, n.4, p.485-510, 2007.

GIL, E. et al. Variable rate application of plant protection products in vineyard using ultrasonic sensors. Crop Protection, Surrey, v.26, n.8, p.1287-1297, 2007.

HABERLE, T.J.; AGOSTINI J.P.; ACUÑA, L. E. Resultados de tres años de ensayo en el ajuste de la tecnología de "Tree Row Volume" (TRV) para el control de mancha negra en naranja Valencia. Revista de investigaciones agropecuarias, Buenos Aires, v.37, n.2, p.193 $-197,2011$.

LIMBERGER, A.R. Avaliação da deposição da calda de pulverização em função do tipo de ponta e do volume aplicado na cultura do feijão. 2006. 51p. Dissertação (Mestrado em Agronomia) - Universidade Estadual do Oeste do Paraná, Campus de Marechal Cândido Rondon, Marechal Cândido Rondon, 2006.

MATIELLO, J.B. et al. Cultura de café no Brasil: Novo Manual de Recomendações. Rio de Janeiro e Varginha: MAPA/PROCAFÉ, 2010. 542 p.

MATTHEWS, G.A. Developments in application technology. Environmentalist, Paris, v.28, n.1, p.19-24, 2008.

MATUO, T. Técnica de aplicação de defensivos agrícolas. Jaboticabal: Funep, 1990. 139p. 
REDE DE AGRICULTURA SUSTENTÁVEL. Norma para obtenção do selo de

367 certificação Rainforest Alliance: Medidas tomadas para obtenção da certificação. Disponível em: $<$ http://www.san.ag/biblioteca/docs/SAN-S-1-

369 1.2_Sustainable_Agriculture_Standard.pdf >. Acesso em: 06 de Fev, 2016.

370 RONCHI, C.P.; DA MATTA, F.M. Aspectos fisiológicos do café conilon. In: FERRÃO, R.G. 371 et al. (Ed). Café Conilon. Vitória: Seag/Incaper, 2007. p.95-115.

372 RUAS, R.A.A. et al. Proposta de método para a inspeção em pulverizadores 373 hidropneumáticos. Coffee Science, Lavras, v.10, n.1, p.76-82, 2015.

374 SANCHEZ-HERMOSILLA, J. et al. Volume application rate adapted to the canopy size in 375 greenhouse tomato crops. Scientia Agricola, Piracicaba, v.70, n.6, p.390-396, 2013.

376 SANTINATO, F. et al. Análise quali-quantitativa da operação de colheita mecanizada de café em duas safras. Coffee Science, Lavras, v.9, n.4, p.495-505, 2014.

378 SCAPIN, M.S. et al. Tree-row-volume-based sprays of copper bactericide for control of citrus canker. Crop Protection, Surrey, v.77, p.119-126, 2015.

380 SILVA, B.M. et al. Deposição da calda de pulverização aplicada com pontas de jato plano em 381 diferentes partes da planta de soja (Glycine max) e milho (Zea mays). Engenharia na 382 agricultura, Campina Grande, v.22, n.1, p.17-24, 2014. 


\section{5. $\quad 3^{\circ}$ ARTIGO: INFLUÊNCIA DA DENSIDADE FOLIAR NA DISTRIBUIÇÃO DE CALDA NO DOSSEL DO CAFEEIRO (Coffea arabica L.)}

\subsection{RESUMO}

RESUMO: A falta de adequação do volume de calda aplicado no alvo pode resultar em baixa eficácia e contaminação ambiental. Assim, objetivou-se avaliar a influência das características do dossel na distribuição de calda na cultura do café (Coffea arabica L.). Os tratamentos foram aplicados em um talhão de Coffea arabica L. cultivar Catuaí Vermelho-144, com volume vegetativo médio de $12501 \mathrm{~m}^{3} \mathrm{ha}^{-1}$. Os tratamentos foram dispostos em esquema de parcelas sub-subdivididas, sendo: três densidades foliares $\left(2,0 ; 1,0\right.$ e $1,5 \mathrm{~kg} \mathrm{~m}^{-3}$ planta $\left.^{-1}\right)$ constituindo as parcelas, cinco volumes de calda (200; 300; 500; 600 e $800 \mathrm{~L} \mathrm{ha}^{-1}$ ) constituindo as subparcelas e três posições no dossel do cafeeiro (Terço superior, mediano e inferior) constituindo as sub-subparcelas, com quatro repetições. As avaliações foram realizadas nos meses de Março, Julho e Dezembro de 2015. As variáveis analisadas foram: deposição de calda, densidade de gotas (DEN), diâmetro mediano volumétrico (DMV) das gotas e amplitude relativa (SPAN) do espectro de gotas. A densidade $1,0 \mathrm{~kg} \mathrm{~m}^{-3}$ planta $^{-1}$ proporcionou deposição de calda superior às densidades de 1,5 e 2,0 $\mathrm{kg} \mathrm{m}^{-3}$ planta $^{-1}$ nas posições superior, mediana e inferior. Na posição mediana a densidade foliar $2,0 \mathrm{~kg} \mathrm{~m}^{-3}$

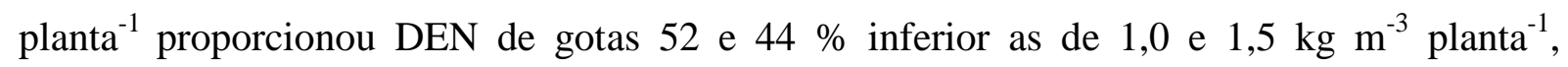
respectivamente. O DMV médio foi de $184 \mu \mathrm{m}$ e o SPAN de 1,3. Conclui-se que o aumento da densidade foliar proporciona redução significativa na distribuição de calda no interior do dossel das plantas de café.

Termos para indexação: Arquitetura das plantas, vazão, penetração de calda. 


\section{INFLUENCE OF DENSITY LEAF IN CALDA DISTRIBUTION IN CANOPY}

\section{COFFEE (Coffea arabica L.)}

\subsection{Abstract}

ABSTRACT: The inadequacy of the spray volume applied to the target can result in low efficiency and environmental contamination. The objective was to evaluate the influence of canopy characteristics in the distribution of syrup in coffee (Coffea arabica L.). The treatments were applied in a Coffea arabica L. cultivar plot Red-144 Catuaí with average growing volume of $12501 \mathrm{~m}^{3} \mathrm{ha}^{-1}$. The treatments were arranged in sub-scheme of split plots, being three foliar densities $\left(2.0,1.0\right.$ and $\left.1.5 \mathrm{~kg} \mathrm{~m}^{-3} \mathrm{plant}^{-1}\right)$ constituting the plots, five volumes of syrup $\left(200 ; 300 ; 500,600\right.$ and $\left.800 \mathrm{~L} \mathrm{ha}^{-1}\right)$ constituting the subplots and three positions in the coffee canopy (upper Third, middle and lower) constituting the sub-subplots, with four replications. The evaluations were conducted in the months of March, July and December 2015. The variables analyzed were: spray deposition drops density (DD), volume median diameter (VMD) of the droplets and relative amplitude (SPAN) drops spectrum. Density 1.0 $\mathrm{kg} \mathrm{m}^{-3}$ plant $^{-1}$ provided higher spray deposition at densities of 1.5 and $2.0 \mathrm{~kg} \mathrm{~m}^{-3}$ plant $^{-1}$ in top positions, middle and lower. In the middle position the leaf density $2.0 \mathrm{~kg} \mathrm{~m}^{-3}$ plant $^{-1}$ provided DD drops 52 and $44 \%$ lower than the 1.0 to $1.5 \mathrm{~kg} \mathrm{~m}^{-3}$ plant ${ }^{-1}$, respectively. The average VMD was $184 \mathrm{~m}$ and the SPAN 1,3. We conclude that the increase in leaf density provides significant reduction in spray distribution within the canopy of the coffee plants.

Index terms: Architecture of plants, flow, spray penetration.

\subsection{INTRODUÇÃO}

O Brasil destaca-se mundialmente como maior produtor e exportador de café (MAPA, 2015). Para que o País se mantenha nesta posição de destaque, faz-se necessário o manejo fitossanitário dos cafeeiros, principalmente por meio do controle químico, empregando-se 
agrotóxicos. Entretanto, essa operação requer cuidados especiais durante sua realização, sob pena de causar prejuízos à saúde humana e ao meio ambiente. Neste contexto, tem-se buscado, além de realizar aplicações mais seguras, a redução do volume de agrotóxico aplicado.

Para isso, faz-se necessário o conhecimento dos fatores que influenciam na deposição e penetração dos agrotóxicos no dossel do cafeeiro (SILVA et al., 2014). A arquitetura da planta é um desses fatores, posto que, no cafeeiro, com o passar do tempo, há sobreposição dos ramos dos terços superiores aos terços inferiores (Da MATTA et al., 2007). Consequentemente, isso resulta em menor penetração e deposição de calda por unidade de área foliar nos alvos desejados (SOUZA; VELINI; PALLADINI, 2007). Associado a isto, está a densidade foliar (SILVA et al., 2014) que, no cafeeiro, pode ocorrer, dentre outros fatores, devido a desfolha decorrente da colheita (SANTINATO et al., 2014) e variações sazonais que ocorrem em função da disponibilidade hídrica e da variação na temperatura (Da MATTA et al., 2007).

Ademais, outro fator que está diretamente ligado ao sucesso da pulverização de agrotóxicos é o volume de calda aplicado (ROSELL POLO et al., 2009). Independentemente das características do dossel, comumente são aplicados no cafeeiro volumes de calda que variam entre 400 e $800 \mathrm{~L} \mathrm{ha}^{-1}$ (MATIELLO et al., 2010), podendo resultar em perdas durante a aplicação (CUNHA et al., 2005). Uma provável explicação para isto é a escassez de informações sobre o volume de calda e deposição adequadas para que se tenha o controle efetivo de pragas e doenças na cultura do café (SILVA et al., 2008).

Dessa forma, faz-se necessário o estudo das interações dessas características do dossel e volumes de calda na deposição e penetração de calda no dossel do cafeeiro. A partir desses estudos, espera-se fornecer informações que possibilitem a redução de volume de calda sem a 
perda de eficácia nos controles fitossanitários. Assim, objetivou-se avaliar a influência das características do dossel na distribuição de calda na cultura do café (Coffea arabica L.).

\subsection{MATERIAL E MÉTODOS}

O experimento foi conduzido na Fazenda Transagro, município de Rio Paranaíba-MG, localizada em $19^{\circ} 13^{\prime} 0.90^{\prime}$ 'S, longitude 46²0’36.16" O, na região do Cerrado Mineiro. Altitude média de 906 m e clima Cwa de acordo com a classificação de Köppen Geiger. As avaliações foram realizadas em Março, Julho e Dezembro de 2015, no momento em que o cafeeiro encontrava-se nos estádios de enchimento de grãos, maturação e pós-colheita.

Foi utilizado o delineamento inteiramente casualizado com os fatores avaliados dispostos em esquema de parcelas sub-subdivididas, sendo: em níveis de parcelas três densidades foliares $\left(2,0 ; 1,0\right.$ e $1,5 \mathrm{~kg} \mathrm{~m}^{-3}$ planta $\left.^{-1}\right)$, nas subparcelas cinco volumes de calda (200; 300; 500; 600 e $800 \mathrm{~L} \mathrm{ha}^{-1}$ ) e sub-subparcelas três posições do dossel do cafeeiro (Terço superior, mediano e inferior), com quatro repetições. As parcelas foram espaçadas $20 \mathrm{~m}$ entre si e formadas por 20 plantas, tendo como base a linha de aplicação.

O talhão escolhido para receber os tratamentos foi composto por plantas de Coffea arabica L. cultivar Catuaí Vermelho-144, o qual foi implantado em 2005 seguindo espaçamento entre plantas e entre linhas de $0,5 \mathrm{~m}$ e $3,8 \mathrm{~m}$, respectivamente. As plantas apresentavam volume vegetativo médio de $12501 \mathrm{~m}^{3} \mathrm{ha}^{-1}$, durante a realização do experimento. A caracterização das três densidades foi realizada nos meses de Março, Julho e Dezembro de 2015. Para isso foi realizada a derriça manual e pesagem de todas as folhas de três plantas de cada talhão. Assim, de posse das massas médias das plantas, volume vegetativo $\left(\mathrm{m}^{3} \mathrm{ha}^{-1}\right)$ e conhecendo-se a população de plantas por hectare, foi determinada a densidade foliar de cada um dos talhões (Equação 01). 


$$
\mathrm{D}=\frac{\mathrm{M}}{(\mathrm{TRV} / \mathrm{N})}
$$

Em que:

$$
\mathrm{D}=\text { densidade foliar }\left(\mathrm{kg} \mathrm{m}^{-3} \text { planta }^{-1}\right)
$$

$$
\mathrm{M}=\text { massa médias de folhas por planta }(\mathrm{kg}) \text {; }
$$

$$
\mathrm{TRV}=\text { volume vegetativo }\left(\mathrm{m}^{3} \mathrm{ha}^{-1}\right) \text {; }
$$

$$
\left.\mathrm{N}=\text { número de plantas por hectare (plantas } \mathrm{ha}^{-1}\right) \text {. }
$$

Para a realização da avaliação de deposição de calda de pulverização, foi empregado o 107 pulverizador hidropneumático tratorizado Arbus Modelo $2000 \mathrm{TP}$ VA da Jacto ${ }^{\circledR}$, com capacidade para $2.000 \mathrm{~L}$ de calda no tanque, dotado de bomba de pistão modelo JP-190 com vazão de até $190 \mathrm{~L} \mathrm{~min}^{-1}$ e ventilador radial com vazão de ar de $19 \mathrm{~m}^{3} \mathrm{~s}^{-1}$. Ele possuía também arco de pulverização duplo equipado com 36 pontas Magno Jet ${ }^{\circledR}$ (MAG) 1,5 e 3,0 que

111 possuem vazões de 0,56 e $1,13 \mathrm{~L} \mathrm{~min}^{-1}$ na pressão de $300 \mathrm{kPa}$, respectivamente, distribuídas 112 da seguinte forma: parte inferior com cinco pontas MAG3,0, parte mediana com nove pontas 113 MAG1,5 e parte superior com quatro pontas MAG3,0.

114 O trator utilizado foi o NEW HOLLAND ${ }^{\circledR}$ modelo TT 3880, cuja potência a 2.500 $115 \mathrm{rpm}$ é de $44,1 \mathrm{~kW}$ e torque máximo a $1.500 \mathrm{rpm}$ de $200 \mathrm{Nm}$. O pulverizador foi previamente 116 regulado e calibrado ajustando-se a velocidade e pressão para distribuição do volume de calda 117 adequado a cada tratamento. As aplicações foram realizadas com as seguintes condições 118 climáticas: temperatura média foi de $24{ }^{\circ} \mathrm{C}$, umidade relativa média (UR \%) de 61 e 119 velocidade do vento média de $4 \mathrm{~km} \mathrm{~h}^{-1}$.

120 Para verificar a deposição de calda de pulverização no dossel do cafeeiro, adicionou-se 121 à calda de pulverização, o corante azul brilhante (solução aquosa traçadora), nas doses de $1223000 \mathrm{mg} \mathrm{L}^{-1}$. Subsequente a aplicação, coletaram-se oito folhas em três posições no centro do 123 dossel (terço superior, inferior e mediano). Nesses pontos, as folhas foram coletadas tendo como referência o primeiro par de folhas a partir do ramo ortotrópico. 
Após coletadas, as folhas foram acondicionadas em sacos plásticos, lavadas em $20 \mathrm{~mL}$

126 de água destilada e agitadas por trinta segundos. Posteriormente, as folhas foram retiradas da

127 solução resultante e armazenadas em sacos plásticos devidamente identificados de acordo

128 com o ponto amostral e com a repetição. Em laboratório, a solução foi analisada em

129 espectrofotômetro, modelo EVOLUTION-300, utilizando-se comprimento de onda de $625 \mathrm{~nm}$

130 (SILVA et al., 2014), obtendo-se assim, a concentração do corante em cada amostra. As

131 amostras de folhas foram enxugadas e tiveram sua área $\left(\mathrm{cm}^{2}\right)$ mensurada, utilizado o AREA

132 METER LICOR modelo LI - 3000C. De posse das absorbâncias em concentração do corante

133 e da área foliar do segmento realizou-se determinação da deposição de calda $\left(\mu \mathrm{L} \mathrm{cm}^{-2}\right)$

134 (LIMBERGER, 2006) (Equação 02).

$$
\mathrm{D}=\frac{10^{6} \times \mathrm{V} \times[\text { solução }]}{\mathrm{A} \times[\text { calda }]}
$$

$$
\text { Em que: }
$$

$$
\mathrm{D}=\text { deposição de calda }\left(\mu \mathrm{L} \mathrm{cm}^{-2}\right) \text {; }
$$

$\mathrm{V}=$ volume de água utilizado para lavar as folhas (L); [solução] = concentração do corante na solução de lavagem $\left(\mathrm{mg} \mathrm{L}^{-1}\right)$;

144 fixaram-se etiquetas hidrossensíveis no primeiro par de folhas a partir do ramo ortótropico no

145 interior no dossel das plantas (centro da planta) nos três terços das plantas (terço superior,

146 mediano e inferior). Após a aplicação, as etiquetas foram removidas, identificadas e

147 acondicionadas em placas de Petri. Posteriormente, tiveram suas imagens digitalizadas

148 utilizando-se escâner calibrado com resolução de 600 DPI para processamento das imagens

149 das manchas de pulverização no software CIR 1.5. Determinando-se assim, os seguintes 
parâmetros: amplitude relativa (SPAN), diâmetro mediano volumétrico (DMV) $(\mu \mathrm{m})$ e

151 densidade de gotas (DEN) $\left(\right.$ gotas $\left.\mathrm{cm}^{-2}\right)$. de calda e de penetração e deposição das gotas de pulverização no dossel do cafeeiro. Os dados foram submetidos à análise de variância $(\mathrm{P} \leq 0,05)$ e, quando pertinente, procedeu-se a realização do teste de Tukey à $5 \%$ de probabilidade. Em caso de significância da variável quantitativa volume de calda, foi realizada a análise de regressão.

\subsection{RESULTADOS E DISCUSSÃO}

Não houve interação entre densidade foliar x volume de calda x posição no dossel (p > 0,05) para a variável resposta deposição de calda e DEN. No entanto, foi verificada interação entre densidade foliar x posição no dossel $(\mathrm{p}<0,05)$. A densidade de $1,0 \mathrm{~kg} \mathrm{~m}^{-3}$ planta $^{-1}$ proporcionou deposição de calda superior às densidades de 1,5 e 2,0 $\mathrm{kg} \mathrm{m}^{-3}$ planta $^{-1}$ nas posições superior, mediana e inferior, respectivamente. Na posição mediana a densidade foliar de $2,0 \mathrm{~kg} \mathrm{~m}^{-3}$ planta $^{-1}$ proporcionou DEN 52 e $44 \%$ inferior as de 1 e 1,5 , respectivamente (Tabela 1). Esta menor deposição de calda e DEN em detrimento da maior densidade, pode ser atribuída ao fato de que maior quantidade de folhas, com sobreposição entre elas, reduz o depósito de calda por unidade de área foliar (SOUZA; VELINI; PALLADINI, 2007). Este efeito da redução da densidade foliar se dá pelo fato de que, no estádio de pós-colheita, tem-se a ação mecânica de desfolha provocada pela ação das hastes da colhedora (SANTINATO et

171 al., 2014) e restrição hídrica (Da MATTA et al., 2007), favorecendo o aumento da deposição 172 da calda pulverizada. 
TABELA 1- Interação densidade foliar x posição no dossel para as variáveis resposta deposição de calda e densidade de gotas (DEN)

\section{Deposição de calda $\left(\mu \mathrm{L} \mathrm{cm}^{-2}\right)$}

\begin{tabular}{cccc}
\hline $\begin{array}{c}\text { Densidade Foliar } \\
\left(\mathrm{kg} \mathrm{m}^{-3} \text { planta }^{-1}\right)\end{array}$ & Superior & Mediana & Inferior \\
\hline 1,0 & $0,36 \mathrm{aA}$ & $0,29 \mathrm{aA}$ & $0,43 \mathrm{aA}$ \\
1,5 & $0,22 \mathrm{aB}$ & $0,13 \mathrm{aB}$ & $0,09 \mathrm{aB}$ \\
2,0 & $0,17 \mathrm{aB}$ & $0,15 \mathrm{aB}$ & $0,15 \mathrm{aB}$ \\
& $\mathrm{DEN}\left(\right.$ gotas cm $\left.^{-2}\right)$ & $137 \mathrm{aA}$ \\
1,0 & $175 \mathrm{aA}$ & $182 \mathrm{aA}$ & $152 \mathrm{aA}$ \\
2,0 & $165 \mathrm{aA}$ & $158 \mathrm{aA}$ & $110 \mathrm{aA}$
\end{tabular}

Médias seguidas de mesma letra minúscula na linha e maiúscula na coluna não diferem entre si pelo teste de Tukey a 5\% de probabilidade.

Além disso, pôde-se observar que não houve diferença significativa $(\mathrm{p}>0,05)$ entre as médias de deposição de calda proporcionadas pelas três densidades foliares nas três posições no dossel das plantas (Tabela 1). Tal fato pode ser explicado devido a densidade de plantio, de modo que, as plantas estiolaram mais que perfilharam. O que resultou, possivelmente, em

180 crescimento mais uniforme dos ramos plagiotrópicos e consequentemente, em menor

181 sobreposição dos ramos e folhas dos terços inferiores pelos terços superiores (Da MATTA et al., 2007). Minimizando assim, os efeitos desta sobreposição na penetração e deposição de 183 calda nesses pontos. 
187 médio proporcionado pelos volumes de calda nas três densidades foi de 190,183 , e $178 \mu$ m,

188 os quais, segundo ASAE, S-572 podem ser considerados médios (Tabela 2). Assim, de forma

189 geral o DMV e SPAN obtido neste trabalho caracteriza uma pulverização com menores

190 perdas de gotas por deriva (gotas pequenas) e por escorrimento (gotas excessivamente

191 grandes) (CUNHA et al., 2004).

192

TABELA 2- Médias de amplitude relativa (SPAN) e diâmetro mediano volumétrico (DMV) dos espectros de gotas para cada volume de calda, dentro das três densidades foliares avaliadas

\begin{tabular}{ccccccc}
\hline Volume de calda & \multicolumn{3}{c}{ SPAN } & \multicolumn{5}{c}{ DMV } \\
\cline { 2 - 7 }$\left(\mathrm{L} \mathrm{ha}^{-1}\right)$ & 2 & 1 & 1,5 & 2 & 1 & 1,5 \\
\hline 200 & 1.1 & 1.0 & 1.4 & 238 & 216 & 180 \\
300 & 1.8 & 1.2 & 1.0 & 133 & 182 & 233 \\
500 & 1.3 & 1.2 & 1.3 & 221 & 168 & 212 \\
600 & 1.3 & 1.1 & 1.4 & 145 & 184 & 116 \\
800 & 1.0 & 1.1 & 2.2 & 213 & 167 & 151 \\
\hline
\end{tabular}

193

194 Analisando a regressão proporcionada pelos volumes de calda aplicados, verifica-se o

195 incremento na deposição de calda de $0,02 \mu \mathrm{L} \mathrm{cm}^{-2}$ para cada $100 \mathrm{~L} \mathrm{ha}^{-1}$ (Figura 1a). Já em 196 relação a variável resposta DEN, pode-se observar que a densidade foliar $2 \mathrm{~kg} \mathrm{~m}^{-3}$ planta $^{-1}$ 197 proporcionou, para cada $100 \mathrm{~L} \mathrm{ha}^{-1}$, aumento de 9 gotas $\mathrm{cm}^{-2}$, enquanto que as densidades $1 \mathrm{e}$ $1981,5 \mathrm{~kg} \mathrm{~m}^{-3}$ planta $^{-1}$ apresentaram 37 e 34 gotas $\mathrm{cm}^{-2} / 100 \mathrm{~L} \mathrm{ha}^{-1}$ de calda aplicados, 199 respectivamente. Esse efeito também pode ser atribuído, à maior interceptação causada pela 200 barreira foliar à deposição e penetração de calda. Essas informações, aliadas a homogeneidade 
201 de espectro de gotas, indicam a possibilidade de se reduzir o volume de calda aplicado sem

202 que seja afetada a qualidade dos depósitos esperados, possibilitando ajustar-se o volume de 203 caldas às variações de densidade foliar.

204

205
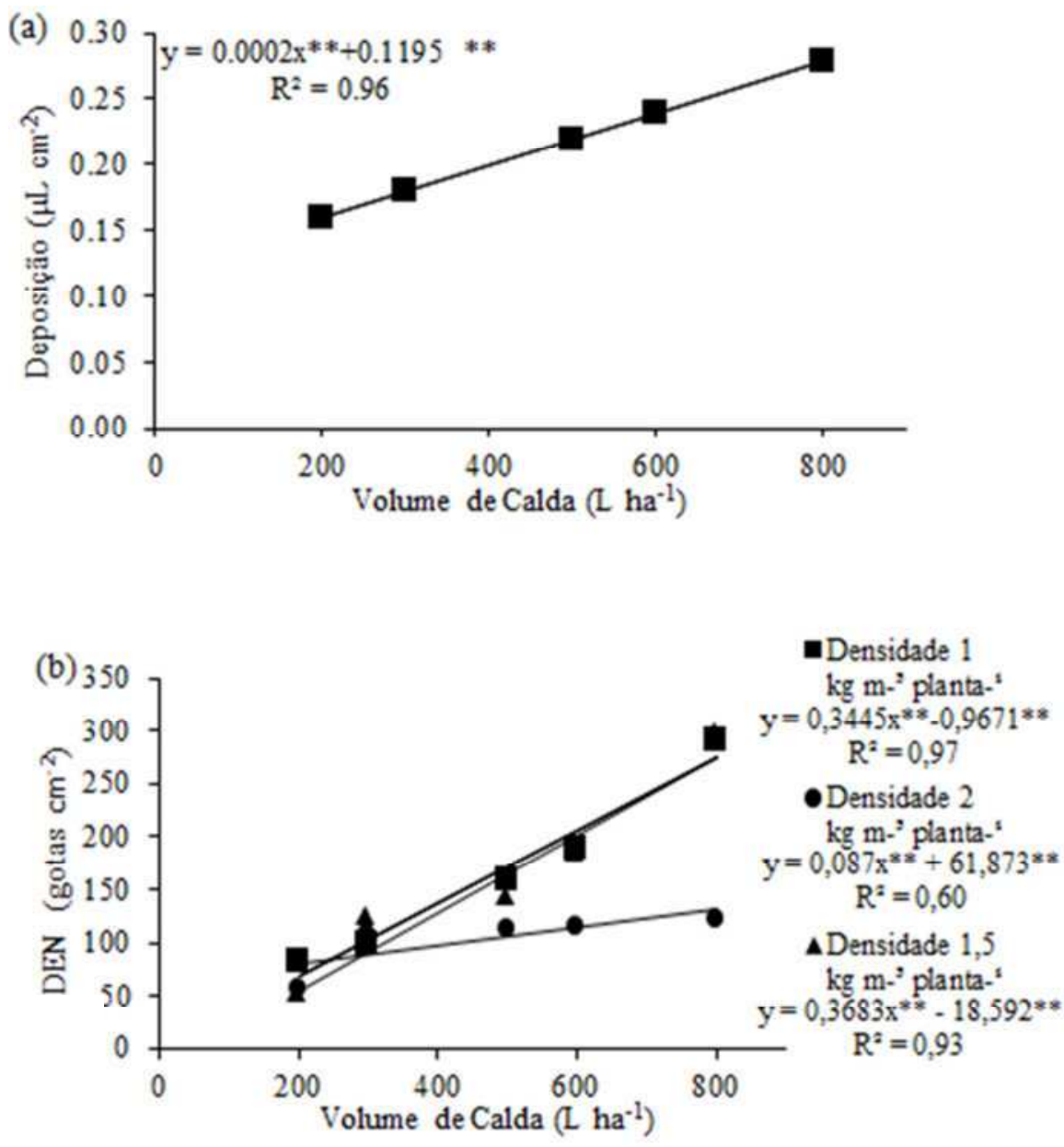

207 FIGURA 1- Deposição de calda (a) e densidade de gotas (DEN) (b) proporcionada pelos cinco volumes de calda aplicados em plantas de Coffea arabica L. 
As variações de densidades foliares tem influência direta na penetração e deposição de

calda de agrotóxicos pulverizada no cafeeiro.

A distribuição uniforme dos ramos e folhas resulta em deposição de calda mais homogênea ao longo do dossel do cafeeiro.

É possível ajustar o volume de calda pulverizado de acordo com a densidade foliar das plantas de café, sem perdas consideráveis nos depósitos obtidos sobre as folhas.

CUNHA, J.P.A.R. et al. Espectro de gotas de bicos de pulverização hidráulicos de jato plano e de jato cônico vazio. Pesquisa Agropecuária Brasileira, Brasília, v.39, n.10, p.977-985, 2004.

CUNHA, J. P. A.R. et al.. Deposição e deriva de calda fungicida aplicada em feijoeiro, em função de bico de pulverização e de volume de calda. Revista Brasileira de Engenharia Agrícola, Campina Grande, v.9, n.1, p.133-138, 2005.

Da MATTA, F.M. et al. Ecophysiology of coffee growth and production. Brazilian Journal Plant Physiology, Londrina, v.19, n.4, p. 485-510, 2007.

LIMBERGER, A.R. Avaliação da deposição da calda de pulverização em função do tipo de ponta e do volume aplicado na cultura do feijão. 2006. 51p. Dissertação (Mestrado em Agronomia) - Universidade Estadual do Oeste do Paraná, Campus de Marechal Cândido Rondon, Marechal Cândido Rondon, 2006.

MATIELLO, J.B. et al. Cultura de café no Brasil: Novo Manual de Recomendações. Rio de Janeiro e Varginha: MAPA/PROCAFÉ, 2010. 542 p.

MINISTÉRIO DA AGRICULTURA PECUÁRIA E ABASTECIMENTO. Café no Brasil 2015. Disponível em: < http://www.agricultura.gov.br/vegetal/culturas/cafe/saiba-mais >. Acesso em: 09 de Abr, 2016.

ROSELL POLO, J. R. et al. A tractor mounted scanning LIDAR for the non-destructive measurement of vegetative volume and surface area of tree-row plantations: a comparison with conventional and destructive measurements. Biosystems Engineering, Bedford, v.102, n.2, p.128-134, 2009.

SANTINATO, F. et al. Análise quali-quantitativa da operação de colheita mecanizada de café em duas safras. Coffee Science, Lavras, v.9, n.4, p.495-505, 2014.

SILVA, R.P. et al. Controle estatístico aplicado ao processo de colheita mecanizada de canade-açúcar. Engenharia Agrícola, Jaboticabal, v.28, n.2, p.292-304, 2008. 
248 SILVA, B.M. et al. Deposição da calda de pulverização aplicada com pontas de jato plano em

249 diferentes partes da planta de soja (Glycine max) e milho (Zea mays). Engenharia na 250 agricultura, viçosa, v.22, n.1, p. 17-24, 2014.

251 SOUZA, R.T.; VELINI, E.D.; PALLADINI, L.A. Aspectos metodológicos para análise de 252 depósitos de pulverizações pela determinação dos depósitos pontuais. Planta Daninha, 253 Viçosa, v.25, n.1, p.195-202, 2007. 


\section{CONCLUSÕES GERAIS}

O aumento da uniformidade de distribuição volumétrica vertical do pulverizador hidropneumático não influencia na eficácia de controle de B. phoenicis.

A diminuição da densidade foliar no período de pós-colheita proporciona maior penetração e deposição de calda no dossel do cafeeiro.

A distribuição uniforme dos ramos e folhas resulta em deposição de calda mais homogênea ao longo dossel do cafeeiro.

O ajuste do índice volumétrico nos estádios fenológicos da cultura do café possibilita a redução do volume de calda aplicado. 


\section{ANEXOS}

Fotos bancada coletora vertical (vertical collector)

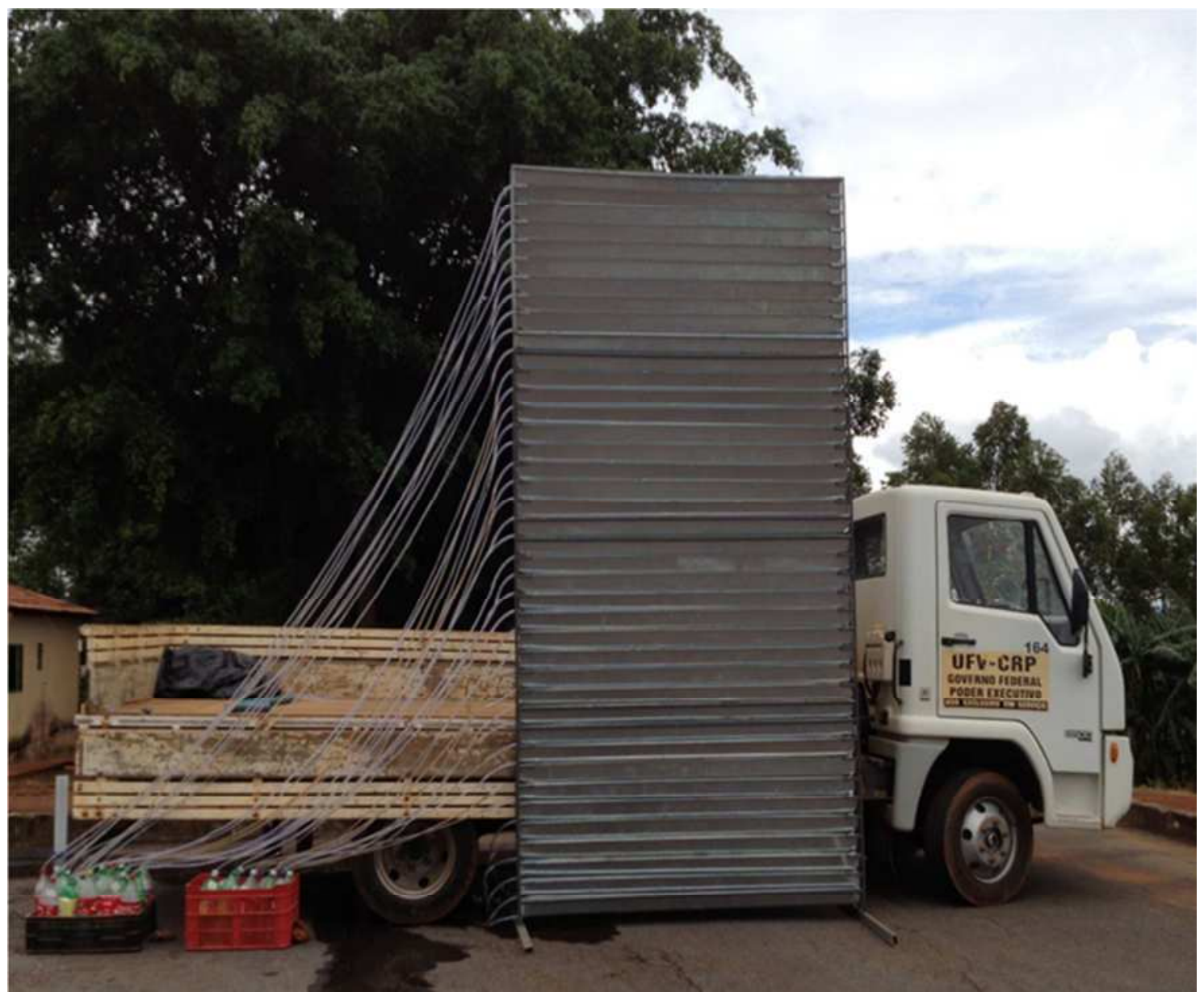




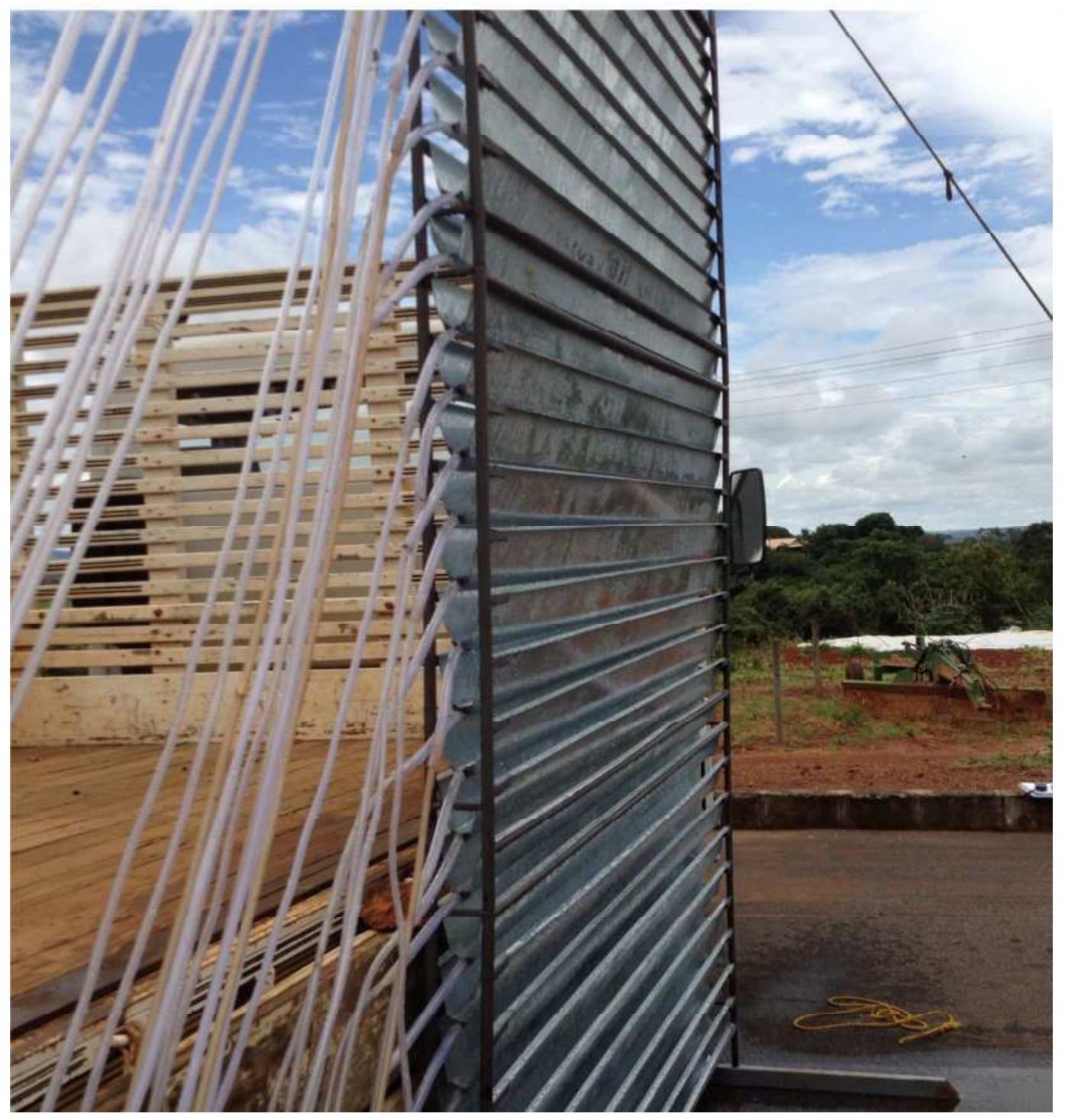




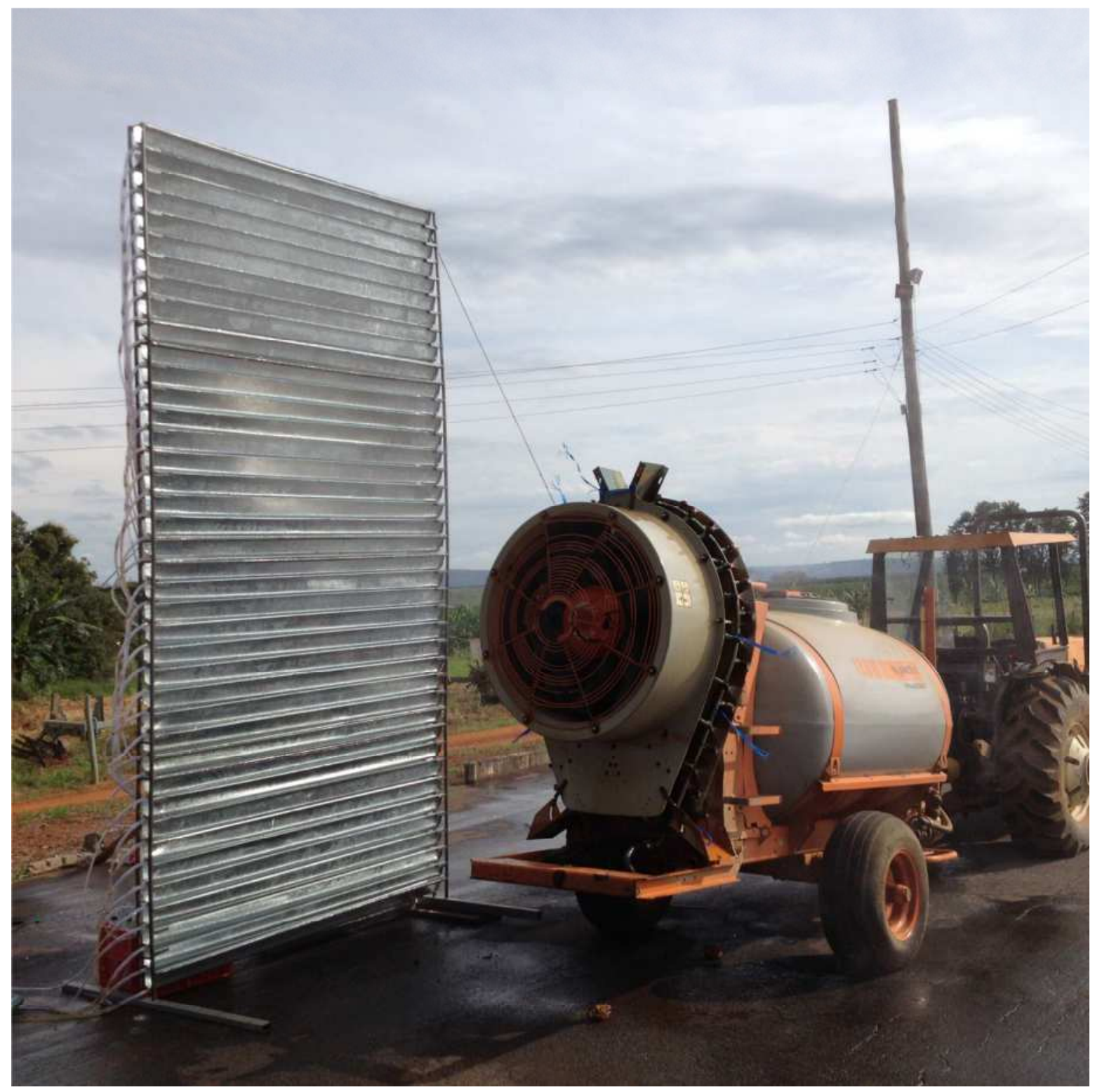

